University of Nebraska - Lincoln

DigitalCommons@University of Nebraska - Lincoln

Retention of Tannin-C is Associated with Decreased Soluble Nitrogen and Increased Cation Exchange Capacity in a Broad Range of Soils

\author{
Jonathan J. Halvorson \\ USDA-ARS Northern Great Plains Research Lab. \\ Javier M. Gonzalez \\ USDA-ARS National Soil Erosion Research Lab. \\ Ann E. Hagerman \\ Miami University
}

Follow this and additional works at: https://digitalcommons.unl.edu/usdaarsfacpub

\begin{abstract}
Halvorson, Jonathan J.; Gonzalez, Javier M.; and Hagerman, Ann E., "Retention of Tannin-C is Associated with Decreased Soluble Nitrogen and Increased Cation Exchange Capacity in a Broad Range of Soils" (2013). Publications from USDA-ARS / UNL Faculty. 1458.

https://digitalcommons.unl.edu/usdaarsfacpub/1458
\end{abstract}

This Article is brought to you for free and open access by the U.S. Department of Agriculture: Agricultural Research Service, Lincoln, Nebraska at DigitalCommons@University of Nebraska - Lincoln. It has been accepted for inclusion in Publications from USDA-ARS / UNL Faculty by an authorized administrator of DigitalCommons@University of Nebraska - Lincoln. 


\section{Retention of Tannin-C is Associated with Decreased Soluble Nitrogen and Increased Cation Exchange Capacity in a Broad Range of Soils}

\author{
Jonathan J. Halvorson* \\ USDA-ARS \\ Northern Great Plains Research Lab. \\ Mandan, ND 58554 \\ Javier M. Gonzalez \\ USDA-ARS \\ National Soil Erosion Research Lab. \\ West Lafayette, IN 47907 \\ Ann E. Hagerman \\ Dep. of Chemistry and Biochemistry \\ Miami Univ. \\ Oxford, $\mathrm{OH} 45056$
}

Phenolic compounds, called tannins, can be retained by soil and affect soluble $\mathrm{N}$ but have been studied in only a few soil types. Surface samples $(0-10 \mathrm{~cm})$, collected from the United States and Canada, were treated with water (Control) or solutions containing procyanidin, catechin, $B-1,2,3,4,6$-pentagalloyl-O-Dglucose (PGG), tannic acid, gallic acid, or methyl gallate. Soluble $\mathrm{C}$ and $\mathrm{N}$ in treatment supernatants and after incubation $\left(16 \mathrm{~h}, 80^{\circ} \mathrm{C}\right)$ were measured to determine retention of treatment $\mathrm{C}$ and effects on soluble $\mathrm{N}$ and cation exchange capacity (CEC). Retention varied significantly with treatment (T) and soil order (S) and was greatest for PGG > tannic acid > procyanidin > catechin > methyl gallate > gallic acid and in Alfisols, Aridisols and Mollisols compared Ultisols. However, differences among soil orders were observed only for strongly retained compounds $(T \times S, P<0.001)$. Extraction of soluble $\mathbf{N}$ was decreased by gallic acid and tannins, especially PGG, but unaffected by methyl gallate or catechin. All treatments decreased soluble $\mathbf{N}$ from Aridisols while Entisols were less affected by tannins $(T \times S, P<0.01)$. Soil CEC was significantly increased by tannins but unaffected by other compounds. However, CEC increased more in Aridisols than in Mollisols or Ultisols and treatment effects were small and unvarying in Ultisols $(\mathrm{T} \times \mathrm{S}, \mathrm{P}<$ 0.001). Changes to both soluble $N$ and CEC were linearly related with retention of treatment C. Tannins produced effects associated with improved soil quality on a broad range of soils and may have a role in land management.

Abbreviations: $\mathrm{CEC}$, cation exchange capacity; EC, electrical conductance; ODE, oven dry equivalent; $\mathrm{PB}$, Prussian blue; PGG, $ß-1,2,3,4,6$-pentagalloyl-O-D-glucose; S, soil order; soluble $\mathrm{C}$, soluble carbon; soluble $\mathrm{N}$, soluble nitrogen; $\mathrm{T}$, treatment; Trt- $\mathrm{C}_{\text {final }}$, final retention of treatment carbon by soil; $\mathrm{Trt}_{-} \mathrm{C}_{\text {ret, }}$ initial retention of treatment carbon by soil; $\triangle \mathrm{CEC}$, net changes in cation exchange capacity attributable to treatments; $\Delta \mathrm{Sol}-\mathrm{N}$, net changes in extraction of soluble nitrogen attributable to treatments.

$\mathrm{T}$ Tannins are polyphenolic plant secondary compounds with molecular weights typically in the range 500 to $3000 \mathrm{~g} \mathrm{~mol}^{-1}$. Like other phenolics, tannins are redox active and form complexes with metal ions such as $\mathrm{Fe}(\mathrm{III})$ or $\mathrm{Al}(\mathrm{III})$. The defining characteristic of tannins is their ability to form cross-linked, complexes with protein (Hagerman, 2012). Lower molecular weight non-tannin phenolics may bind protein but do not form precipitable complexes. Tannins can account for a significant proportion of biomass in some terrestrial plants (Kuiters, 1990; Matthews et al., 1997), and are broadly classed as hydrolyzable or condensed (Haslam, 1981; Salminen and Karonen, 2011). Hydrolyzable tannins are galloyl esters and their derivatives attached to polyol cores, while

Soil Sci. Soc. Am. J. 77:1199-1213

doi:10.2136/sssaj2012.0326

USDA is an equal opportunity provider and employer. Mention of trade names or commercial products in this publication is solely for the purpose of providing specific information and does not imply recommendation or endorsement by the U.S. Department of Agriculture.

Received 28 Sept. 2012.

*Corresponding author (Jonathan.Halvorson@ars.usda.gov).

(C) Soil Science Society of America, 5585 Guilford Rd., Madison WI 53711 USA All rights reserved. No part of this periodical may be reproduced or transmitted in any form or by any means, electronic or mechanical, including photocopying, recording, or any information storage and retrieval system, without permission in writing from the publisher. Permission for printing and for reprinting the material contained herein has been obtained by the publisher. 
condensed tannins are oligomeric and polymeric flavan-3-ols (Quideau et al., 2011).

The importance of phenolic plant secondary compounds, including tannins, to soil functions has emerged as their effects on biological, chemical, and physical processes have come to light. (Halvorson et al., 2011; Hättenschwiler and Vitousek, 2000; Horner et al., 1988; Kraus et al., 2003a; von Lützow et al., 2006). When exuded from roots or leached from living or dead plant materials, phenolic compounds can affect soil physical properties and nutrient cycling by forming complexes with mineral fractions of the soil, by stabilizing soil organic matter, proteins or other organic forms of $\mathrm{N}$, and by direct or indirect stimulation or inhibition of soil microorganisms (Adamczyk et al., 2013; Cesco et al., 2012; Fabre et al., 2010; Makoi and Ndakidemi, 2007). However, their impacts may be influenced by specific tannin and soil characteristics and remain to be fully elucidated (Kraus et al., 2003b, Schmidt et al., 2012, Smolander et al., 2012). Our earlier work focused on understanding the initial effects of tannins and related non-tannin phenolics on soil processes and characteristics related to management of soil organic matter and nutrient cycling (Halvorson et al., 2012a; Halvorson and Gonzalez, 2008; Halvorson et al., 2012b; Halvorson et al., 2011; Halvorson et al., 2009; Schmidt et al., 2012). When added to soil, tannic acid affected the recovery and composition of Bradford-reactive soil protein, associated with glomalin. Retention of treatment $\mathrm{C}$ by soil was rapid, much greater for tannins than non-tannin subunits, and greater for hydrolyzable gallotannins than condensed tannins (proanthocyanidins). Significant amounts of retained tannin-C remained in soil even after repeated rinses with hot water and retention appeared to be favored by soil organic matter and influenced by depth, soil amendments, and soil texture. In response to increasing compound concentrations or repeated applications, tannins produced patterns of cumulative retention, consistent with saturable binding of the treatment $\mathrm{C}$ to soil with evidence for a maximum loading capacity. Relatively high retention of tannin-C by soil was accompanied by increases in cation exchange capacity. Solubility of soil N, particularly organic forms, was reduced by hydrolyzable tannins and related compounds and to a lesser degree by condensed tannins. The effects of treatment varied with the temperature but were little affected by soil amendments. However, reductions of soluble $\mathrm{N}$ were stronger in pasture than forest soil. We also found tannins and related compounds can increase the solubility of soil metals such as $\mathrm{Ca}$ and $\mathrm{Mn}$ and mitigate the toxic effects of $\mathrm{Al}$ on roots (Kinraide and Hagerman, 2010).

Together, these studies suggest tannins may have a role in the management of agricultural soils where the quantity and quality of soil organic matter and nutrient cycling has economic and environmental consequences (eg., Dominati et al., 2010; Robinson et al., 2013; Robinson et al., 2009). However, the initial reactions of tannins with soil, as well as subsequent biological transformations, have been evaluated for only a few soil types and land uses and thus critical assessment of their potential role in managing soil quality has lagged. More systematic, comparative studies are needed to provide information to devise new strategies to achieve desired management goals.

The objective of this study was to document the initial interactions of tannins and closely related non-tannin phenolic compounds with a broad variety of soils. We hypothesized that the patterns we observed for pasture and forest sites from West Virginia, USA (Halvorson et al., 2012b; Halvorson et al., 2011; Halvorson et al., 2009) would be reflected consistently in samples acquired from across the United States and Canada representing a wide variety of land uses and differing management styles. We treated samples of these soils with solutions containing chemically well-defined hydrolyzable and condensed tannins, (polymers) and related non-tannin phenolic substances (monomers). We determined the retention treatment $\mathrm{C}$ in soil and treatment effects on soluble $\mathrm{N}$ and cation exchange capacity to fit within the analytical framework of our earlier studies and to relate to important soil parameters such as the accumulation or retention of organic matter or plant nutrients.

\section{MATERIALS AND METHODS Soils}

Samples of surface soil $(0-10 \mathrm{~cm})$ representing five soil orders, a wide variety of land uses, and differing management styles were acquired from various locations distributed across 22 states and a Canadian province (Ontario) (Appendix A). Each sample $(n=66)$ was a comprised of multiple cores collected from an area and in such a fashion so as to accurately represent the local management conditions. Composite samples were sieved $(2 \mathrm{~mm})$, dried to a constant mass at $55^{\circ} \mathrm{C}$, and stored at room temperature until further analysis.

Basic soil properties were determined for each composite sample (Table 1). Total soil $\mathrm{C}$ and $\mathrm{N}$ were determined on untreated soils after dry oxidation with a FlashEA 1112 NC Analyzer (CE Elantech, Lakewood, NJ) using CE Elantech NC reference soil $(3.5 \% \mathrm{C}$ and $0.37 \% \mathrm{~N})$ and $K$-factor calibration with aspartic acid as a standard. Total soil organic $\mathrm{C}$ was determined similarly from samples acidified with $100 \mu \mathrm{L} 6 \mathrm{M} \mathrm{HCl}$ and oven dried $\left(60^{\circ} \mathrm{C}\right.$ for $\left.2-3 \mathrm{~h}\right)$. Sample textures were determined by hydrometer (Midwest Labs, Omaha, NE, www.midwestlabs.com). Soil $\mathrm{pH}$ and electrical conductance (EC) were measured by electrode (1:1 soil/water). Cation exchange capacity (CEC) of soils was measured at the soil $\mathrm{pH}$ by exchange with cobalt hexamine trichloride at a concentration of $0.01667 \mathrm{M}$ and expressed as centimoles of positive charge per kilogram oven dried equivalent soil ( $\mathrm{cmol}_{\mathrm{c}} \mathrm{kg}^{-1}$ ODE soil) (Ciesielski and Sterckeman, 1997a, 1997b, ISO 23470:2007, 2007).

\section{Test Compounds}

Soil samples were treated with solutions containing model tannins or non-tannin phenolic compounds (organic acids and flavonoids), selected to represent a range of phenolic compounds of varying complexity present in the plant-soil continuum (Gallet and Lebreton, 1995). Our representative condensed tannin was a polymeric flavonoid-based procyanidin isolated from sorghum 
Table 1. Soil properties $(0-10 \mathrm{~cm})+$.

\begin{tabular}{|c|c|c|c|c|c|c|c|c|c|}
\hline Soil type & Total soil C & $\begin{array}{l}\text { Total organic } \\
\text { soil C }\end{array}$ & Total soil N & Sand & Silt & Clay & $\mathrm{pH}$ & EC & CEC \\
\hline & & & $-\%$ & & & & & $\mu S \mathrm{~cm}^{-1}$ & $\overline{\mathrm{cmol}_{\mathrm{C}} \mathrm{kg}^{-1}}$ \\
\hline Average $(n=66)$ & $\begin{array}{l}1.88 \pm 0.15 \\
(0.35-6.46)\end{array}$ & $\begin{array}{l}1.57 \pm 0.12 \\
(0.30-4.60)\end{array}$ & $\begin{array}{l}0.15 \pm 0.01 \\
(0.04-0.40)\end{array}$ & $\begin{array}{l}41.5 \pm 2.7 \\
(8-89)\end{array}$ & $\begin{array}{l}43.5 \pm 2.3 \\
(7-76)\end{array}$ & $\begin{array}{l}14.9 \pm 0.9 \\
(2-34)\end{array}$ & $\begin{array}{l}6.8 \pm 0.1 \\
(4.3-8.7)\end{array}$ & $\begin{array}{l}262 \pm 22 \\
(62-863)\end{array}$ & $\begin{array}{l}12.6 \pm 0.8 \\
(1.7-26.5)\end{array}$ \\
\hline Alfisols $(n=10)$ & $\begin{array}{l}1.80 \pm 0.29 \\
(0.35-3.74)\end{array}$ & $\begin{array}{l}1.74 \pm 0.28 \\
(0.30-3.60)\end{array}$ & $\begin{array}{l}0.16 \pm 0.02 \\
(0.04-0.23)\end{array}$ & $\begin{array}{l}25.8 \pm 7.4 \\
(8-84)\end{array}$ & $\begin{array}{l}52.0 \pm 5.2 \\
(10-66)\end{array}$ & $\begin{array}{l}22.2 \pm 2.5 \\
(6-30)\end{array}$ & $\begin{array}{l}6.4 \pm 0.3 \\
(4.3-7.2)\end{array}$ & $\begin{array}{l}225 \pm 58 \\
(82-700)\end{array}$ & $\begin{array}{l}11.2 \pm 1.4 \\
(5.0-18.2)\end{array}$ \\
\hline Aridisols $(n=5)$ & $\begin{array}{l}3.66 \pm 0.76 \\
(1.85-6.46)\end{array}$ & $\begin{array}{l}1.09 \pm 0.17 \\
(0.74-1.64)\end{array}$ & $\begin{array}{l}0.13 \pm 0.02 \\
(0.09-0.18)\end{array}$ & $\begin{array}{l}39.6 \pm 8.5 \\
(18-56)\end{array}$ & $\begin{array}{l}48.0 \pm 8.3 \\
(30-68)\end{array}$ & $\begin{array}{l}12.4 \pm 2.2 \\
(8-20)\end{array}$ & $\begin{array}{l}8.4 \pm 0.0 \\
(8.3-8.4)\end{array}$ & $\begin{array}{l}307 \pm 77 \\
(176-571)\end{array}$ & $\begin{array}{l}14.3 \pm 1.7 \\
(10.9-18.5)\end{array}$ \\
\hline Entisols $(n=6)$ & $\begin{array}{l}0.87 \pm 0.10 \\
(0.65-1.27)\end{array}$ & $\begin{array}{l}0.68 \pm 0.07 \\
(0.37-0.87)\end{array}$ & $\begin{array}{l}0.08 \pm .01 \\
(0.06-0.09)\end{array}$ & $\begin{array}{l}62.2 \pm 4.4 \\
(48-75)\end{array}$ & $\begin{array}{l}26.2 \pm 4.0 \\
(13-38)\end{array}$ & $\begin{array}{l}11.7 \pm 1.0 \\
(8-14)\end{array}$ & $\begin{array}{l}8.0 \pm 0.3 \\
(7.1-8.6)\end{array}$ & $\begin{array}{l}325 \pm 110 \\
(131-863)\end{array}$ & $\begin{array}{l}14.1 \pm 1.7 \\
(9.8-18.9)\end{array}$ \\
\hline Mollisols $(n=33$ ) & $\begin{array}{l}2.09 \pm 0.20 \\
(0.39-4.80)\end{array}$ & $\begin{array}{l}1.93 \pm 0.19 \\
(0.36-4.60)\end{array}$ & $\begin{array}{l}0.18 \pm 0.02 \\
(0.04-0.40)\end{array}$ & $\begin{array}{l}35.0 \pm 0.3 \\
(10-70)\end{array}$ & $\begin{array}{l}49.3 \pm 3.0 \\
(16-76)\end{array}$ & $\begin{array}{l}15.7 \pm 1.1 \\
(4-34)\end{array}$ & $\begin{array}{l}6.7 \pm 0.2 \\
(5.1-8.7)\end{array}$ & $\begin{array}{l}299 \pm 29 \\
(84-854)\end{array}$ & $\begin{array}{l}15.9 \pm 0.9 \\
(9.4-26.5)\end{array}$ \\
\hline Ultisols $(n=12)$ & $\begin{array}{l}1.15 \pm 0.13 \\
(0.54-1.93)\end{array}$ & $\begin{array}{l}1.08 \pm 0.13 \\
(0.50-1.83)\end{array}$ & $\begin{array}{l}0.10 \pm 0.01 \\
(0.04-0.18)\end{array}$ & $\begin{array}{l}63.0 \pm 4.8 \\
(38-89)\end{array}$ & $\begin{array}{l}27.5 \pm 4.3 \\
(7-54)\end{array}$ & $\begin{array}{l}9.5 \pm 1.6 \\
(2-18)\end{array}$ & $\begin{array}{l}6.1 \pm 0.2 \\
(5.1-7.4)\end{array}$ & $\begin{array}{l}138 \pm 29 \\
(62-419)\end{array}$ & $\begin{array}{l}3.4 \pm 0.4 \\
(1.7-5.5)\end{array}$ \\
\hline
\end{tabular}

grain [Sorghum bicolor (L.) Moench] (Hagerman, 2002; Schofield et al., 1998). We also evaluated tannic acid, a commercially available, but imprecisely defined mixture of galloyl esters, and $\beta$-1,2,3,4,6-pentagalloyl$O$-D-glucose (PGG), a well-defined gallotannin purified from tannic acid (Hagerman, 2002). Non-tannin phenolics included the flavonoid catechin, the phenolic acid, gallic acid, and its ester, methyl gallate (Fig. 1, Table 2).

\section{Retention of Treatment Carbon and Effects on Soluble Nitrogen}

Sorption/desorption of test compounds and effects on soluble $\mathrm{N}$ were determined from patterns of soluble carbon (soluble C) and nitrogen (soluble $\mathrm{N}$ ) in supernatants after an application of a cool $\left(23^{\circ} \mathrm{C}\right)$ treatment solution and after a subsequent incubation in hot water $\left(80^{\circ} \mathrm{C}\right)$. Both cool and hot water extractions were employed because they have been associated with different pools of labile $\mathrm{C}$ and $\mathrm{N}$ in soil and featured in recent work (Halvorson and Gonzalez, 2008; Halvorson et al., 2009). The $C$ and $N$ extracted from soil with cool water are thought to correlate to recent inputs such as fertilizer, lime, manure, or soluble plant<smiles>Oc1cc(O)c2c(c1)OC(c1ccc(O)c(O)c1)C(O)C2</smiles>

(a) (+)-Catechin<smiles>Oc1cc(O)c2c(c1)O[C@H](c1ccc(O)c(O)c1)C(O)C2c1c(O)cc(O)c2c1O[C@H](c1ccc(O)c(O)c1)[C@H](O)[C@H]2c1c(O)cc(O)c2c1O[C@H](c1ccc(O)c(O)c1)[C@@H](O)C2</smiles>

(d) Sorghum procyanidin<smiles>O=C(O)c1cc(O)c(O)c(O)c1</smiles><smiles>COC(=O)c1cc(O)c(O)c(O)c1</smiles>

(b) Gallic acid

(c) Methyl gallate

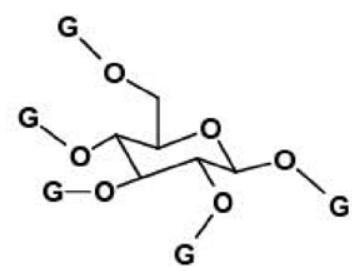

(e) $\beta-1,2,3,4,6$-Pentagalloyl-O-D-glucose

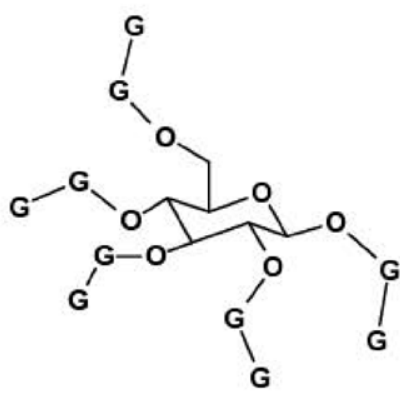

(f) Tannic acid $\mathrm{G}=$ gallic acid ester

Fig. 1. Chemical structures for (a) (+)-Catechin, (b) Gallic acid, (c) Methyl gallate, (d) Sorghum procyanidin, (e) $\beta$-1,2,3,4,6-pentagalloyl-O-D-glucose (PGG), and (f) Tannic acid. The structure shown for tannic acid is a representative molecule since it is an imprecisely defined mixture of galloyl esters. 
residues while $\mathrm{C}$ and $\mathrm{N}$ recovered after hot water incubation are positively correlated with soil microbial biomass $\mathrm{C}$ and $\mathrm{N}$, mineralizable $\mathrm{N}$ and total carbohydrates. (Curtin et al., 2006; Ghani et al., 2003).

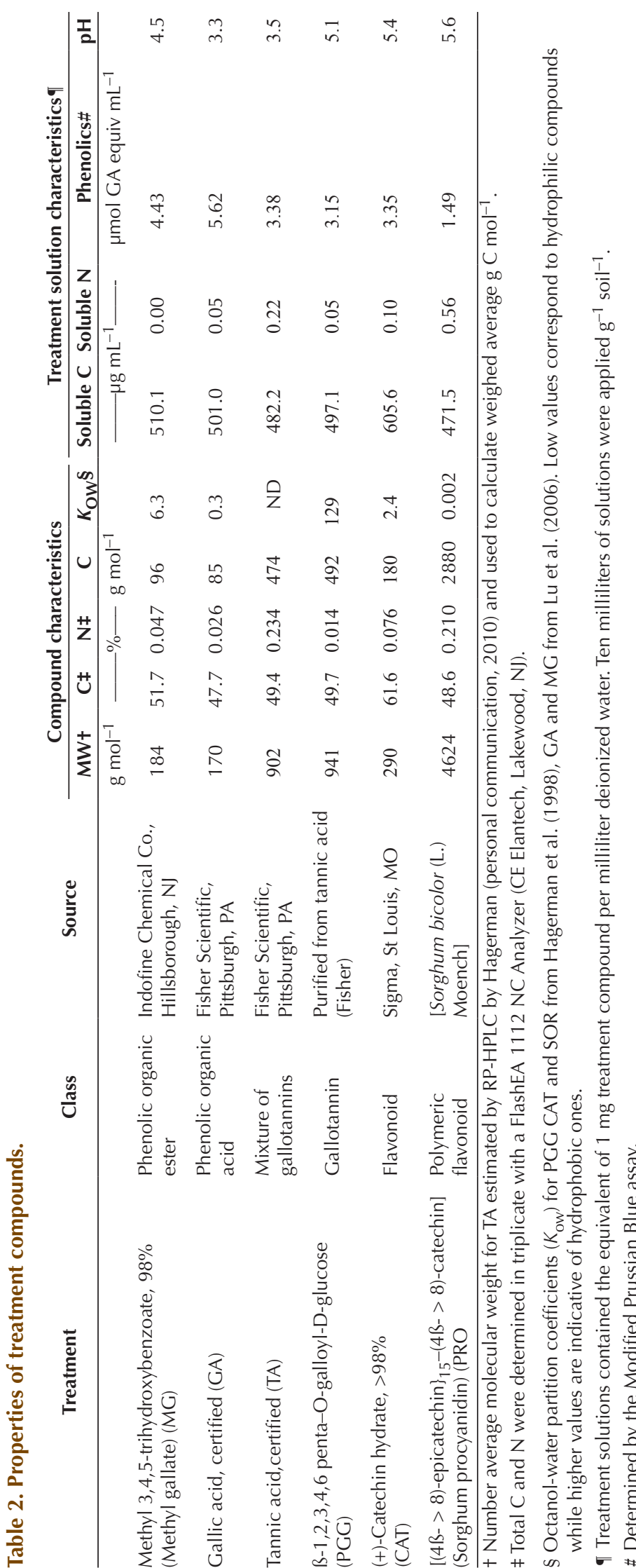

Seven subsamples ( $3 \mathrm{~g}$ ), obtained from of each soil sample, were weighed into tared Oak Ridge polypropylene centrifuge tubes $(50 \mathrm{~mL}$, nominal). These were treated with $30 \mathrm{~mL}$ of a test solution to yield a final amendment of $10 \mathrm{mg}$ test compound $\mathrm{g}^{-1}$ soil or with $30 \mathrm{~mL}$ of deionized water (control). After reciprocal shaking at $200 \mathrm{rpm}$ for $1 \mathrm{~h}$ at room temperature, samples were centrifuged for $3 \mathrm{~min}$ at 11,952 $\mathrm{g}$ and decanted. Sample tubes were weighed to account for the effects of retained solution while supernatants were analyzed for soluble $\mathrm{C}$ and $\mathrm{N}$ with a Shimadzu TOC-VCPN analyzer equipped with a TNM-1 module (Shimadzu Scientific Instruments, Columbia, MD). Sample pellets were stored for $<4 \mathrm{~h}$ in the original tubes in a refrigerator until they could be prepared for the hot water incubation. For the hot water incubation, water $(30 \mathrm{~mL})$ was added to all soil samples, which were then vortexed, incubated overnight in a water bath $\left(16 \mathrm{~h}, 80^{\circ} \mathrm{C}\right)$, and assayed for soluble $\mathrm{C}$ and $\mathrm{N}$.

Total phenolics initially added by test solutions and remaining in the supernatants after treatment were determined with the modified Prussian blue (PB) assay for total phenols (Graham, 1992; Hagerman, 2002; Schofield et al., 1998) using gallic acid as the standard. This assay is a colorimetric determination of phenolics and other oxidizable compounds which cannot distinguish between tannins and other phenolic substances. The proportion of added PB-reactive material remaining in treatment supernatants was compared against retention of treatment $\mathrm{C}$ to confirm retention of phenolic compounds by the soils. Values for hot water-soluble C, and N, and PB were corrected to account for carryover from the previous treatment step and all data were adjusted to an oven dry equivalent (ODE) soil basis.

Initial retention of treatment $\mathrm{C}$ by soil was calculated as:

Trt- $\mathrm{C}_{\text {ret }}=$ Trt- $\mathrm{C}_{\text {added }}-\left(\right.$ Sol- $\mathrm{C}_{\text {trt }}-$ Sol-C $\left._{\text {control }}\right)[1]$ where $\operatorname{Trt}-\mathrm{C}_{\text {added }}$ is the soluble carbon added in treatment solutions (Table 2), and Sol- $\mathrm{C}_{\mathrm{Trt}}$ and Sol- $\mathrm{C}_{\text {control }}$ are soluble carbon extracted from treated and control samples, respectively.

The final retention of treatment $\mathrm{C}$ after the hot water incubation was determined as

$$
\text { Trt- } \mathrm{C}_{\text {final }}=\text { Trt- } \mathrm{C}_{\text {ret }}-\left(\text { HWSol- } \mathrm{C}_{\text {trt }}-\text { HWSol-C } \mathrm{C}_{\text {control }}\right) \text { [2] }
$$

where HWSol- $\mathrm{C}_{\mathrm{Trt}}$ and HWSol- $\mathrm{C}_{\text {control }}$ are soluble carbon extracted from treated and control samples with hot water. Values for initial and final retention of treatment $\mathrm{C}$ were determined in both absolute ( $\mathrm{mg} \mathrm{kg}^{-1} \mathrm{ODE}$ soil), and relative (percent of added treatment $\mathrm{C}$ ) terms.

Treatment effects on the extraction of soluble $\mathrm{N}$ were calculated relative to the control values and used to determine if treatments decreased (net treatment $<$ net control) or increased (net treatment $>$ net control) extraction of soluble $\mathrm{N}$ from soil. The net effects of treatments on the extraction of soluble $\mathrm{N}$ after the initial treatment and after the hot water incubation were determined as:

$$
\Delta \text { Sol-N }=\text { Sol-N } \mathrm{trt}-\text { Sol-N }_{\text {control }}[3]
$$


where Sol- $\mathrm{N}_{\text {trt }}$, and Sol- $\mathrm{N}_{\text {control }}$ indicate the amount of net soluble nitrogen extracted from soil samples treated with phenolic compounds or water alone, respectively.

\section{Measurements of Final Total Soil Carbon and Cation Exchange Capacity}

The soil pellet remaining in tubes after the hot water incubation was dried $\left(55^{\circ} \mathrm{C}\right)$, and a portion assayed for total soil-C and $\mathrm{CEC}$ as described above. Although we expected changes in soil$\mathrm{C}$ to be the net result of the $\mathrm{C}$ added by the treatments balanced against losses of soluble $\mathrm{C}$, we also compared Trt- $\mathrm{C}_{\text {final }}$ with the difference between treated and control samples (i.e., total $\mathrm{C}$ in treated soil-total C in control samples) to account for experimental error introduced by sample handling.

As with soluble $\mathrm{N}$, treatment effects on soil cation exchange capacity (CEC) were calculated relative to the control values. The net changes in CEC attributable to treatments, $(\triangle \mathrm{CEC})$, were determined as:

$\triangle \mathrm{CEC}=\left(\mathrm{CEC}_{\text {trt }}-\mathrm{CEC}_{\text {control }}\right)[4]$

where $\mathrm{CEC}_{\text {trt }}$, and $\mathrm{CEC}_{\text {control }}$ indicate the $\mathrm{CEC}$ measured in soil samples treated with phenolic compounds or water alone, respectively.

\section{Statistical Analyses}

We analyzed initial retention of treatment $\mathrm{C}$ and $\triangle$ Sol-N by ANOVA with SAS 9.2 and PROC MIXED using a model that contained both fixed (treatment) and random (sample location) effects (Littell et al., 1996; SAS, 1999). The KenwardRoger (KR) option was used to calculate degrees of freedom while covariance structures were selected to minimize Akaike's Information Criterion. Multiple pairwise comparisons of means were performed using the Tukey-Kramer method using a value of $5 \%$ (i.e., $P<0.05$ ) as the minimum criterion for significance unless otherwise noted. Assumptions of normality were evaluated and appropriate data transformations identified with SAS/ ASSIST. Bivariate relationships between treatment effects and several soil properties were characterized by Spearman correlations $(\rho)$, using PROC CORR. Compared to the Pearson corre- lation, Spearman correlations do not assume bivariate normality and are less biased by outliers. Significant deviation of $\Delta$ Sol-N and $\triangle \mathrm{CEC}$ from zero, indicative of a meaningful change in the extraction of soluble $\mathrm{N}$ or cation exchange capacity due to the treatment, was determined by the LSMEANS statement in PROC MIXED. Values indicated in text and graphs are the arithmetic mean, \pm the standard error of the mean, expressed on oven-dry soil basis.

\section{RESULTS AND DISCUSSION Retention of Treatment Carbon}

The control treatment (water) extracted an average $297 \pm$ $23 \mathrm{mg} \mathrm{kg}^{-1}$ soluble $\mathrm{C}$ from soils. In contrast, differing amounts of $\mathrm{C}$ added in treatment solutions were retained by treated soils $(P \leq 0.001)$ resulting in net increases to soil $\mathrm{C}$ (Table 3$)$. The greatest retention, observed for PGG, accounted for more than $70 \%$ of the $\mathrm{C}$ added in the treatment solution. Soils retained about $33 \%$ of procyanidin from sorghum. The lowest retentions were observed for non-tannin phenolic compounds, gallic acid, methyl gallate, and catechin, equivalent to 8,12 , and $17 \%$ of added treatment C, respectively (Table 3). Retention of all treatment compounds was positively correlated with soil organic C, total N, silt, clay, and CEC and negatively related to sand. Soil $\mathrm{pH}$ was negatively correlated with retention of gallic acid but positively correlated with retention of tannic acid and PGG. Soil $\mathrm{pH}$, however, was unrelated to retention of methyl gallate, catechin, or procyanidin. Electrical conductivity was positively correlated with retention of catechin, procyanidin, tannic acid, and PGG but not related to retention of gallic acid or methyl gallate (Table 3).

Patterns of treatment retention observed across a broad geographical range of soil types and management were consistent with those observed earlier for West Virginia forest and pasture soils and for Oregon soils amended with various kinds of organic matter (Halvorson et al., 2012a, 2011). Retention of tannins and related non-tannin compounds in soil has been linked to compound polarity, size, and molecular weight with the greatest retention by larger, non-polar compounds (Halvorson et al., 2011;

Table 3. Retention of treatment $\mathrm{C}+$ following a $1 \mathrm{~h}$ shake at room temperature $\left(23^{\circ} \mathrm{C}\right)$ and Spearman correlation coefficients $(\rho)$ with selected soil attributes.

\begin{tabular}{|c|c|c|c|c|c|c|c|c|c|c|}
\hline Treatment & \multicolumn{2}{|c|}{ Retention of treatment C } & Total organic soil C & Total soil $\mathrm{N}$ & Sand & Silt & Clay & pHw & EC $\ddagger$ & CEC \\
\hline & \multicolumn{2}{|c|}{$\mathrm{mg} \mathrm{kg}^{-1}$ soil $\%$ of the total added } & \multicolumn{8}{|c|}{ Spearman correlation coefficients $(\rho)$} \\
\hline Gallic acid & 406 (38) F & $7.9(0.7)$ & $0.72 * * *$ & $0.70^{* * *}$ & $-0.58^{* * *}$ & $0.50^{* * *}$ & $0.40^{* * *}$ & $-0.42 * * *$ & 0.05 & $0.41^{* * *}$ \\
\hline Methyl gallate & $639(39) \mathrm{E}$ & $12.3(0.7)$ & $0.70 * * *$ & $0.72 * * *$ & $-0.51^{* * *}$ & $0.43 * * *$ & $0.39 * *$ & -0.14 & 0.22 & $0.53 * * *$ \\
\hline Catechin & $1025(51) \mathrm{D}$ & $16.6(0.8)$ & $0.73 * * *$ & $0.78^{* * *}$ & $-0.75^{* * *}$ & $0.67 * * *$ & $0.48^{* * *}$ & -0.20 & $0.29 *$ & $0.58^{* * *}$ \\
\hline Procyanidin & $1583(71) \mathrm{C}$ & $32.9(1.5)$ & $0.64^{* * *}$ & $0.71 * * *$ & $-0.56^{* * *}$ & $0.41 * * *$ & $0.52^{* * *}$ & -0.09 & $0.32 * *$ & $0.41^{* * *}$ \\
\hline Tannic acid & $2576(111) \mathrm{B}$ & $52.4(2.2)$ & $0.41^{* * *}$ & $0.51^{* * *}$ & $-0.53^{* * *}$ & $0.42^{* * *}$ & $0.43^{* * *}$ & $0.32 * *$ & $0.51^{* * *}$ & $0.57^{* * *}$ \\
\hline PGG & 3579 (125) A & $70.7(2.4)$ & $0.46^{* * *}$ & $0.56 * * *$ & $-0.53 * * *$ & $0.44 * * *$ & $0.43^{* * *}$ & $0.29^{*}$ & $0.53 * * *$ & $0.63^{* * *}$ \\
\hline \multicolumn{11}{|c|}{${ }^{*}$ Significant at the 0.05 level. } \\
\hline \multicolumn{11}{|c|}{ ** Significant at the 0.01 level. } \\
\hline \multicolumn{11}{|c|}{ *** Significant at the 0.001 level. } \\
\hline \multicolumn{11}{|c|}{$\begin{array}{l}\text { Treatment solutions consisted of a water control or supplied } 10 \text { mg of gallic acid, methyl gallate, catechin, procyanidin tannin from sorghum, } \\
\text { tannic acid or } B-1,2,3,4,6 \text {-penta-galloyl-O-D-glucose (PGG) } \mathrm{g}^{-1} \text { soil. Data are the arithmetic averages (standard error) of all samples ( } n=66 \text { ). } \\
\text { Treatment differences in retention of treatment C were determined by ANOVA and are delineated by letter. }\end{array}$} \\
\hline \multicolumn{11}{|c|}{ ₹ EC = electrical conductance; $\mathrm{CEC}=$ cation exchange capacity. } \\
\hline
\end{tabular}


Schmidt et al., 2012). Sorghum procyanidin is a polar extended molecule with high molecular mass compared to the smaller, hydrophobic and disk-like PGG (Table 2; Feldman and Smith, 1996; Hagerman et al., 1998; Kondo et al., 2006). Sorption of hydrophobic compounds is correlated with the amount of soil organic matter (e.g., Karickhoff et al., 1979; Luthy et al., 1997) but also affected by the composition of organic matter (e.g., Chen et al., 2009; Xing, 1997). Based on the importance of hydrophobic and hydrogen bonding interactions between polyphenols and biomolecules such as proteins (Hagerman, 2012) we speculate that the affinities of polyphenols for soils might involve similar interactions. Under favorable conditions of $\mathrm{pH}$, ionic interactions between the weakly acidic polyphenols and soils might be important. Weak forces such as Van der Waals interactions could also contribute to soil-polyphenol interactions. The affinity of soil for the very nonpolar PGG may be dominated by hydrophobic interactions but the more polar compounds such as sorghum procyanidin might interact mainly through hydrogen bonding.

Retention has also been related to physical properties of soil such as texture. Using a small number of soils $(n=6)$ Schmidt et al. (2012) found sorption of a simple phenolic, methyl gallate, was strongly related to soil organic matter but it was best modeled as a function of silt and sand composition. Conversely the sorption of a more complex polyphenol was best modeled as a positive function of sand, silt, clay, and $\mathrm{pH}$. The results of this study, however, suggest retention of treatment $\mathrm{C}$ is increased in the presence of silt and clay (Table 3). In comparison to sand, silt and clay fractions possess greater specific surface area and usually contain greater amounts of metal oxides (particularly iron) which are important for microaggregation and stabilization of soil organic matter and may increase the sorption of tannins via formation of tannin-metal complexes (Kaal et al., 2005, Pronk et al., 2011).

Estimates of retention of treatment $\mathrm{C}$, determined with Eq. [1], generally matched the disappearance of $\mathrm{PB}$ reactive phenolics from treatment supernatants, especially for procyanidin, tannic acid, and PGG (Fig. 2d-2f). We also observed close agreement between retention of treatment $\mathrm{C}$ and disappearance of $\mathrm{PB}$ reactive phenolics for all treatment compounds in our earlier studies conducted on soils with $\mathrm{pH}$ ranging from 4.0 to 5.3 (Halvorson et al., 2012a; 2011). However, disproportionately high losses of $\mathrm{PB}$ phenolics together with low retention of treatment $\mathrm{C}$ were observed for non-tannin phenolic compounds, gallic acid, methyl gallate, and catechin in soil samples with a $\mathrm{pH}$ higher than 8 (Fig. 2a-2c). Phenolics are not stable at high pH, so loss of phenolics from our system could be explained by chemical decomposition. The rate and $\mathrm{pH}$ dependence of decomposition may vary for different polyphenolics depending on chemi- (a)

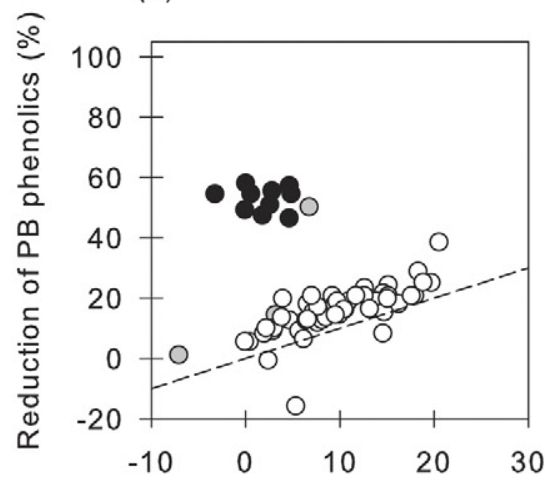

(d)

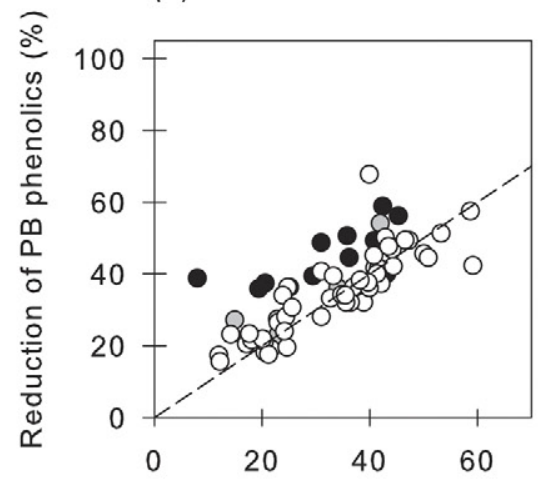

Retention of treatment-C (\%) (b) Methyl gallate

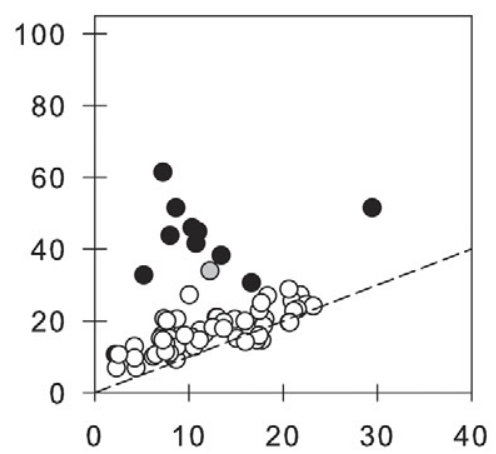

(e) Tannic acid

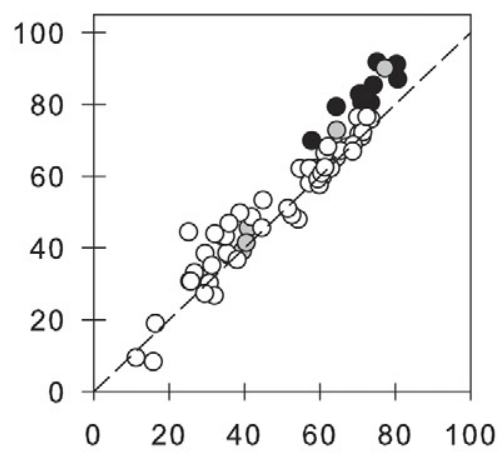

Retention of treatment-C (\%) (c) Catechin

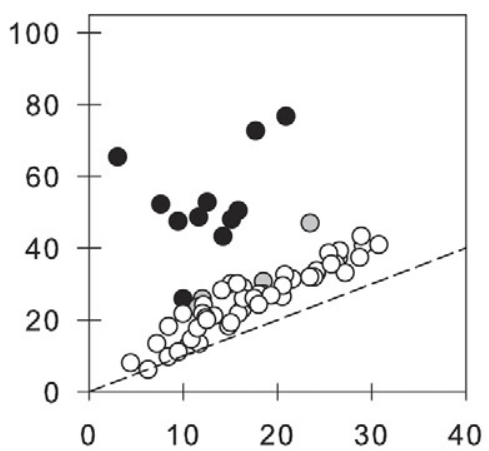

(f)

PGG

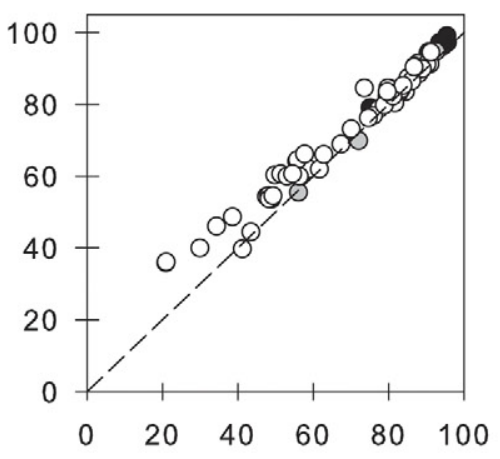

Retention of treatment-C (\%)

Fig. 2. The relationship between retention of treatment $\mathrm{C}$ and reduction of total Prussian Blue (PB) phenolics in supernatants (\% of added, Table 2). Open symbols indicate a starting soil $\mathrm{pH}<7.5$ while those in gray and black indicate a starting $\mathrm{pH}$ between 7.5 and 8.0 and $>8.0$, respectively. The dashed line indicates a slope of 1:1. 
cal structure and position of substituents such as the phenolic hydroxyl groups. Friedman and Jürgens (2000) found that gallic acid and catechin were decomposed at high $\mathrm{pH}$ with different stabilities for the two compounds that may be related structural variations. The similarity between the amount of treatment $\mathrm{C}$ retained and disappearance of $\mathrm{PB}$ phenolics observed for tannins reflects the role of both $\mathrm{pH}$ and chemical nature of the sorptive surface in the sorption-desorption experiments. We hypothesize there is a complicated interplay between sorption and decomposition of natural phenolics in soil systems.

\section{Treatment Effects on Extraction of Soluble Nitrogen}

The control treatment (water) extracted an average $40.7 \pm$ $3.2 \mathrm{mg} \mathrm{kg}^{-1}$ soluble $\mathrm{N}$ from soils, an amount similar to that extracted with the tannic acid or procyanidin treatments (Table 4). In contrast, the methyl gallate and, to a lesser extent, catechin treatments extracted more soluble $\mathrm{N}$ from samples than the control; gallic acid, and PGG extracted less. Reductions in soluble N could be attributed to formation of complexes with proteins (cf. Knicker, 2004; Kraus et al., 2003a; Rillig et al., 2007) or other $\mathrm{N}$-containing compounds (Adamczyk et al., 2011, 2013) influenced by specific tannin chemistry (Coq et al., 2010; Kraus et al., 2003b; Mutabaruka et al., 2007) and the quantity and quality of soil N (Talbot and Finzi, 2008).

The $\Delta$ Sol-N (Eq. [3]) for methyl gallate and catechin treatments was strongly positively correlated with several soil variables including retention of treatment $\mathrm{C}$, total organic soil $\mathrm{C}$ and $\mathrm{N}$, silt, and EC and negatively correlated with the amount of sand and soil $\mathrm{pH}$ (Table 4). In addition, $\Delta$ Sol-N for catechin was positively correlated with clay content and CEC. Average $\Delta$ Sol-N for gallic acid was positively correlated with silt content and negatively correlated with soil $\mathrm{pH}$. The $\Delta$ Sol-N for PGG was correlated to soil texture, positively for silt and clay and negatively with sand. Average $\Delta$ Sol-N for the tannic acid treatment was correlated to the same soil variables observed collectively for gallic acid and PGG, significantly positive with silt and clay content but negatively with sand and $\mathrm{pH}$. Tannic acid is a het- erogeneous mixture containing gallic acid and gallates including PGG. Average $\Delta$ Sol-N for procyanidin was negatively correlated with a single soil variable, $\mathrm{pH}$.

Correlation coefficients were useful for describing the relationship between pairs of variables and provided additional insight to the apparent lack of effect of tannic acid or procyanidin on soluble $\mathrm{N}$ suggested by the univariate averages. The average $\Delta$ Sol-N for tannic acid and procyanidin treatments did not differ from 0 , implying that these treatments did not affect the solubility of soil $\mathrm{N}$, yet the $\Delta$ Sol-N for both of these compounds was negatively correlated with soil $\mathrm{pH}$. Such a pattern indicates they extracted more $\mathrm{N}$ than the water control when soil $\mathrm{pH}$ was low and conversely, extracted less $\mathrm{N}$ from soil than the water control when soil $\mathrm{pH}$ was high. Scatter plots indicated that the $\mathrm{pH}$ at which this switch occurred was between 6 and 7 (data not shown). Because $\mathrm{pH}$ can affect the formation of tannin-protein complexes (Hagerman, 2012; Hagerman and Butler, 1981; Kraus et al., 2003a), we postulate that at low $\mathrm{pH}$, tannins may form soluble tannin protein complexes. At high soil $\mathrm{pH}$ we speculate that tannins immobilize $\mathrm{N}$ by forming stable tanninprotein complexes that remain tightly soil-bound.

\section{Response to the Hot Water Incubation}

Incubation in hot water, following the initial treatments, extracted about $540 \mathrm{mg} \mathrm{kg}^{-1} \mathrm{C}$ from control samples (Fig. 3). Similar quantities of soluble $\mathrm{C}$ were extracted from samples previously treated with gallic acid, procyanidin, and methyl gallate, indicating no significant desorption of treatment $\mathrm{C}$ or treatment effects on soluble pools of soil organic matter. Conversely, the quantity of soluble $\mathrm{C}$ extracted from samples treated with catechin, tannic acid, or PGG exceeded the control by about 150 to $180 \mathrm{mg}$ of $\mathrm{C} \mathrm{kg}^{-1}$ soil, suggesting release of weakly retained treatment $\mathrm{C}$. These releases were equivalent to 18,7 , and $4 \%$, of retained treatment $\mathrm{C}$ for catechin, tannic acid, and PGG respectively (Table 3).

The hot water incubation also extracted about $54 \mathrm{mg}$ of $\mathrm{N} \mathrm{kg}^{-1}$ from control samples, an amount greater than

Table 4. Treatment effectst on $\Delta \mathrm{Sol}-\mathrm{N} \neq$ following a $1 \mathrm{~h}$ shake at room temperature $\left(23^{\circ} \mathrm{C}\right)$ and Spearman correlation coefficients ( $\rho$ ) with selected soil attributes.

\begin{tabular}{|c|c|c|c|c|c|c|c|c|c|c|}
\hline Treatment & $\Delta$ Sol-N & $\begin{array}{l}\text { Retention of } \\
\text { treatment C }\end{array}$ & $\begin{array}{l}\text { Total organic } \\
\text { soil C }\end{array}$ & $\begin{array}{l}\text { Total } \\
\text { soil N }\end{array}$ & Sand & Silt & Clay & $\mathrm{pHw}$ & EC & CEC \\
\hline & $\mathrm{mg} \mathrm{kg}^{-1}$ soil & & & $-S p$ & arman corr & ation coef & icients $(\rho)$ & & & \\
\hline Gallic acid & $-4.1(0.6) \mathrm{D}$ & 0.05 & 0.07 & 0.03 & -0.23 & $0.34^{* *}$ & -0.12 & $-0.38^{* *}$ & 0.03 & -0.12 \\
\hline Methyl gallate & $8.5(0.9) \mathrm{A}$ & $0.41^{* * *}$ & $0.68^{* * *}$ & $0.69^{* * *}$ & $-0.51^{* * *}$ & $0.49^{* * *}$ & 0.23 & $-0.52^{* * *}$ & $0.34^{* *}$ & 0.17 \\
\hline Catechin & $2.1(0.5) \mathrm{B}$ & $0.35^{* *}$ & $0.32^{* *}$ & $0.32^{* *}$ & $-0.52^{* * *}$ & $0.50^{* * *}$ & $0.34^{* *}$ & $-0.35^{* *}$ & $0.39 * *$ & $0.28 *$ \\
\hline Procyanidin§ & $0.3(0.4) \mathrm{C}$ & -0.02 & 0.21 & 0.17 & -0.17 & 0.14 & 0.14 & $-0.64 * * *$ & 0.09 & -0.14 \\
\hline Tannic acid§ & $-0.8(0.6) \mathrm{C}$ & -0.19 & 0.21 & 0.18 & $-0.37^{* *}$ & $0.32 * *$ & $0.34^{* *}$ & $-0.48^{* * *}$ & 0.18 & 0.10 \\
\hline PGG & $-3.4(0.6) \mathrm{D}$ & -0.23 & -0.06 & -0.09 & $-0.36^{* *}$ & $0.30^{*}$ & $0.36^{* *}$ & -0.17 & 0.14 & 0.17 \\
\hline
\end{tabular}

* Significant at the 0.05 level.

** Significant at the 0.01 level.

*** Significant at the 0.001 level.

+ Treatment solutions consisted of a water control or supplied $10 \mathrm{mg}$ of gallic acid, methyl gallate, catechin, procyanidin tannin from sorghum, tannic acid or $\beta-1,2,3,4,6$-penta-galloyl-O-D-glucose (PGG) per g soil. Data are the arithmetic averages (standard error) of all samples $(n=66)$. Treatment differences in retention of treatment $C$ were determined by ANOVA and are delineated by letter.

₹ As calculated with Eq. [3].

$\S$ Not significantly different from the water Control. 


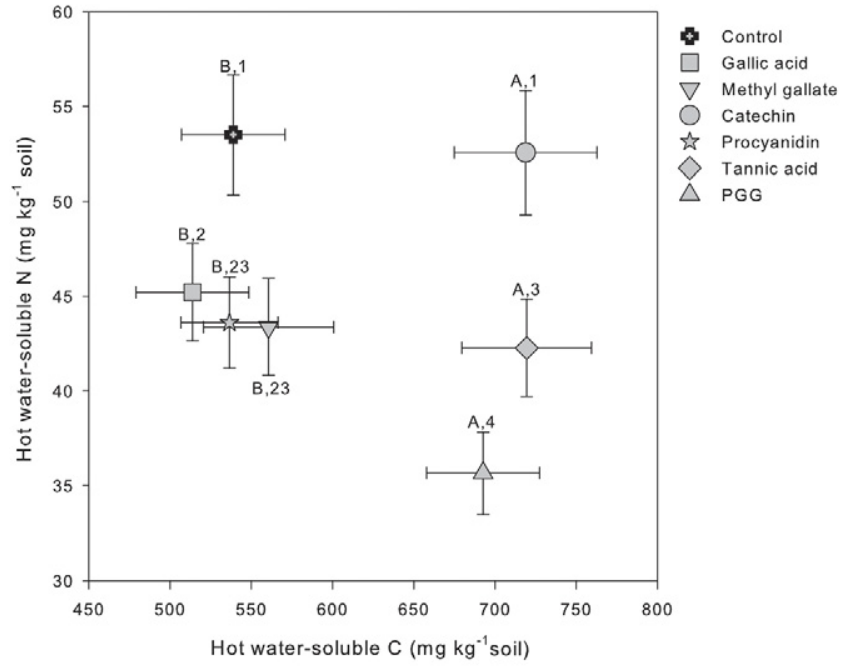

Fig. 3. Soluble $\mathrm{C}$ and $\mathrm{N}$ extracted with a $16 \mathrm{~h}$ hot water $\left(80^{\circ} \mathrm{C}\right)$ incubation (Mean, SEM, $n=66$ ). Treatment differences for soluble $C$ (denoted by letters) and $\mathrm{N}$ (denoted by number) were determined for transformed data with Tukey's HSD $(P<0.05)$.

the initial extraction with $\operatorname{cool}\left(23^{\circ} \mathrm{C}\right)$ water, and similar to the catechin treatment (Fig. 3). Significant reductions in hot water extractable- $\mathrm{N}$ were observed for all other treatments ranging from about $-8 \mathrm{mg} \mathrm{N} \mathrm{kg}^{-1}$ soil for gallic acid to $-18 \mathrm{mg} \mathrm{N} \mathrm{kg}^{-1}$ soil PGG. While the soluble $\mathrm{N}$ extracted with cool water or treatment solutions includes both inorganic and organic $\mathrm{N}$, the $\mathrm{N}$ in the hot water extract is likely to be primarily composed of unspecified organic forms of $\mathrm{N}$ (Curtin et al., 2006; Ghani et al., 2003; Halvorson et al., 2009; Leinweber et al., 1995). Less hotwater soluble $\mathrm{N}$ following treatment with all of the compounds except catechin suggests they increased the ability of organic $\mathrm{N}$ to resist extraction by forming chemical or physical complexes with the soil matrix. We believe that unique features of the catechin structure or reactivity are responsible for its low activity in the hot water extractions.

\section{Analysis by Soil Order}

Our initial attempts to identify a few simple explanatory relationships for treatment effects were hampered by simultaneous significant linear correlations with a number of related soil properties suggesting multicollinearity (Tables 3 and 4 ). We were also unable to uncover significant treatment effects using several selfdefined, subjective, data stratification schemes based on management, such as cropped vs. uncropped, or on relative cultivation disturbance (more vs. less). However, a number of significant patterns emerged when treatment effects were analyzed by soil order. Soil order is a well-established taxonomic concept that provided a clearly defined and geo-referenced scheme for distinguishing among our samples based on an objective rationale. Each soil order represents a unique combination of properties that integrates parent material, vegetation, climate, soil moisture regime, diagnostic horizons, and biological chemical and physical processes (Jenny, 1941; Soil Survey Staff, 1999). We therefore determined treatment effects on $T r t-\mathrm{C}_{\text {final, }}$ and $\Delta$ Sol-N, and $\triangle \mathrm{CEC}$ after the hot-water extraction, using an ANOVA model that included fixed effects of treatment and soil order.

\section{Final Retained Treatment Carbon}

Final retention of treatment $\mathrm{C}$ after the hot water treatment $\left(\right.$ Trt- $\left.\mathrm{C}_{\text {final }}\right)$, varied strongly with treatment $(\mathrm{T})$ and soil order (S) but also exhibited a $\mathrm{T} \times \mathrm{S}$ interaction (all $P \leq 0.001$, Table 5). Treatment effects were arranged similarly within each soil order with values for $\mathrm{PGG}>$ tannic acid $>$ procyanidin $>$ catechin $>$ methyl gallate $>$ gallic acid. Among soil orders, retention was greatest in Alfisols, Aridisols, and Mollisols, the groups that contained relatively large amounts of soil $\mathrm{C}, \mathrm{N}$, and silt and was lowest in poorly developed (Entisols) or degraded (Ultisols), soils characterized by relatively low amounts of soil organic material or largely comprised of sand (Table 1 ). The $\mathrm{T} \times \mathrm{S}$ interaction showed that retention of treatment $\mathrm{C}$ varied among the different soil orders only for strongly retained compounds, especially tannins (Table 5). Significant differences in Trt- $\mathrm{C}_{\text {final }}$ among soil orders could be detected only for PGG, tannic acid, procyanidin, and catechin. Alfisols, Aridisols, and Mollisols retained 76,84 , and $71 \%$ of the PGG treatment, compared to only $49 \%$ by Ultisols. Tannic acid displayed a similar pattern. Sorghum procyanidin was retained more in Alfisols than Entisols, while more catechin was retained in Alfisols than Ultisols. Conversely, soil characteristics had little influence on poorly retained compounds. Only small amounts of the applied gallic acid or methyl gallate remained in soil, about 8 and 12\%, respectively, and did not vary among the soil orders.

The main effects of treatment on $\mathrm{Trt}-\mathrm{C}_{\text {final }}$ were confirmed by direct measurements of total soil C (Fig. 4a). Based on previous studies (Halvorson et al., 2012a) we expected changes in soil $\mathrm{C}$ to be the net result of the $\mathrm{C}$ added by the treatments balanced against losses of soluble $\mathrm{C}$. However the actual measured change of soil C in control samples, a loss of $2418 \pm 425 \mathrm{mg} \mathrm{kg}^{-1}$ soil, was greater than could be attributed to solely to extraction of water-soluble $\mathrm{C}, 836 \pm 51 \mathrm{mg} \mathrm{kg}^{-1}$ soil (Table 5) and a similar disparity between actual and expected soil $\mathrm{C}$ was also observed for the other treatments. The average disparity between actual and expected soil $\mathrm{C}$ observed for all treatments as well as the control $\left(1779 \pm 160 \mathrm{mg} \mathrm{kg}^{-1}\right.$ soil, $\left.n=460\right)$ suggests a common source for unintentional losses of soil C associated with sample handling, perhaps during the decanting step. Assuming similar C losses from all samples due to handling, we accounted for these errors by subtracting the total $\mathrm{C}$ in control samples from the amount in treated samples and found we found good agreement with Trt- $\mathrm{C}_{\text {final }}$, confirming meaningful amounts of each compound remained on soil C (Fig. 4b, Table 5; also Fig. 5b in Halvorson et al., 2011).

\section{Final Effects on Soluble Nitrogen}

Net change in soluble $\mathrm{N}$ after treatments and hot water incubation, $\Delta$ Sol-N, varied with treatment $(P<0.001)$ but also exhibited a significant $\mathrm{T} \times \mathrm{S}$ interaction $(P<0.01)$ (Table 5$)$. Main effects indicated that extraction of soluble $\mathrm{N}$ was not sig- 


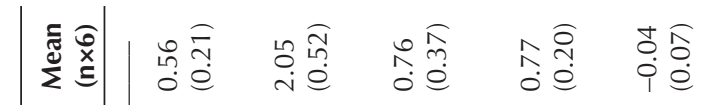

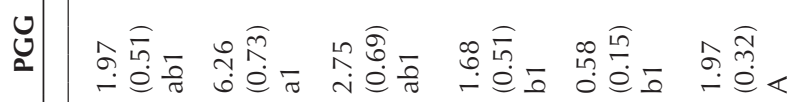

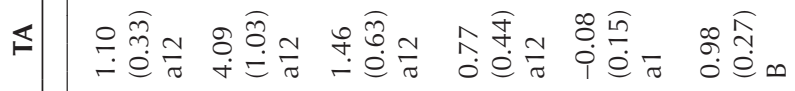

嵌

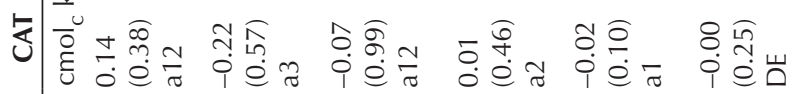

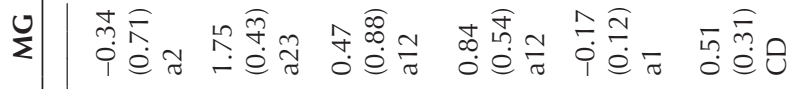

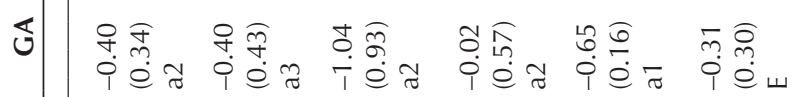

产出|

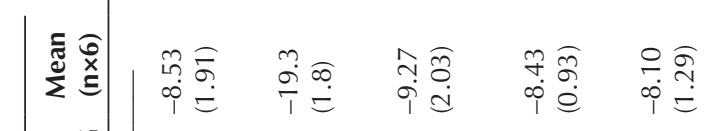

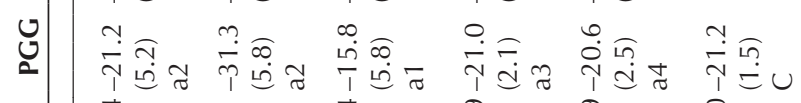

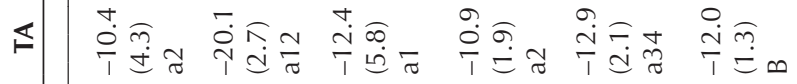

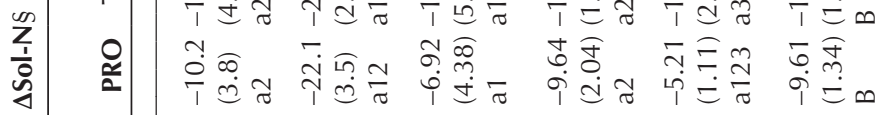

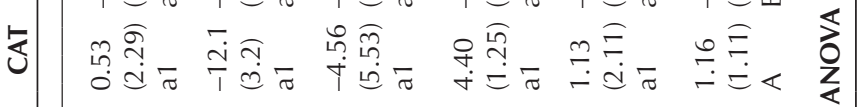

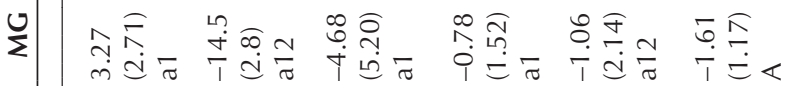

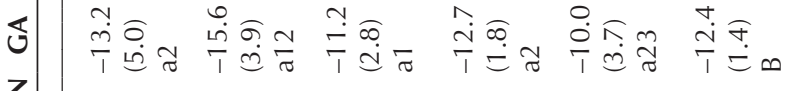

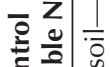

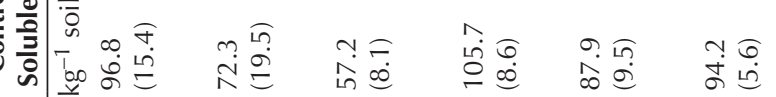

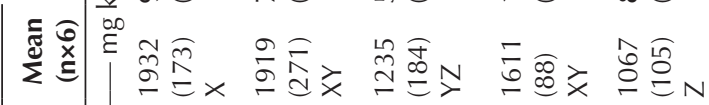

U U U U

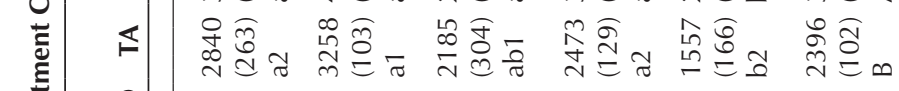

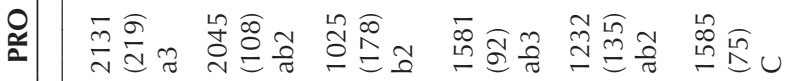

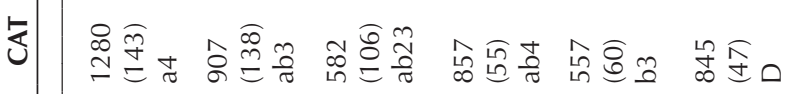

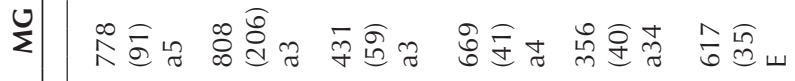

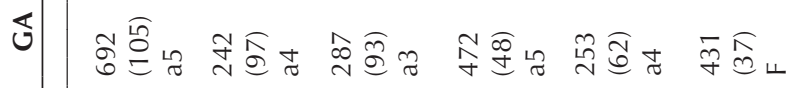

- U

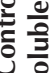

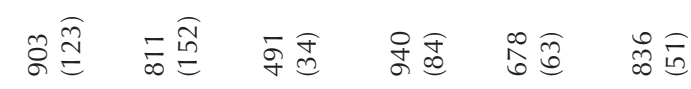

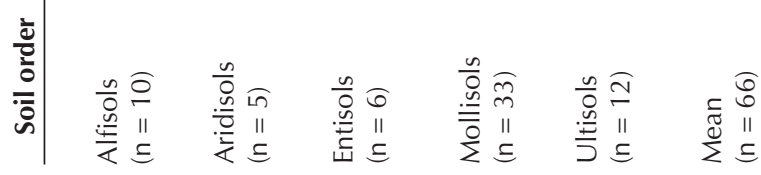

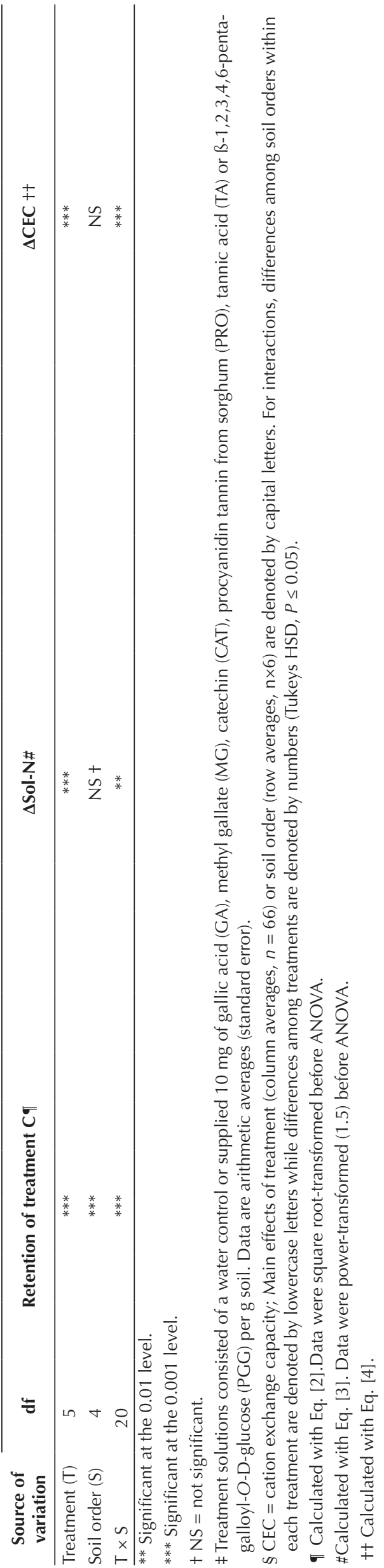


(a)

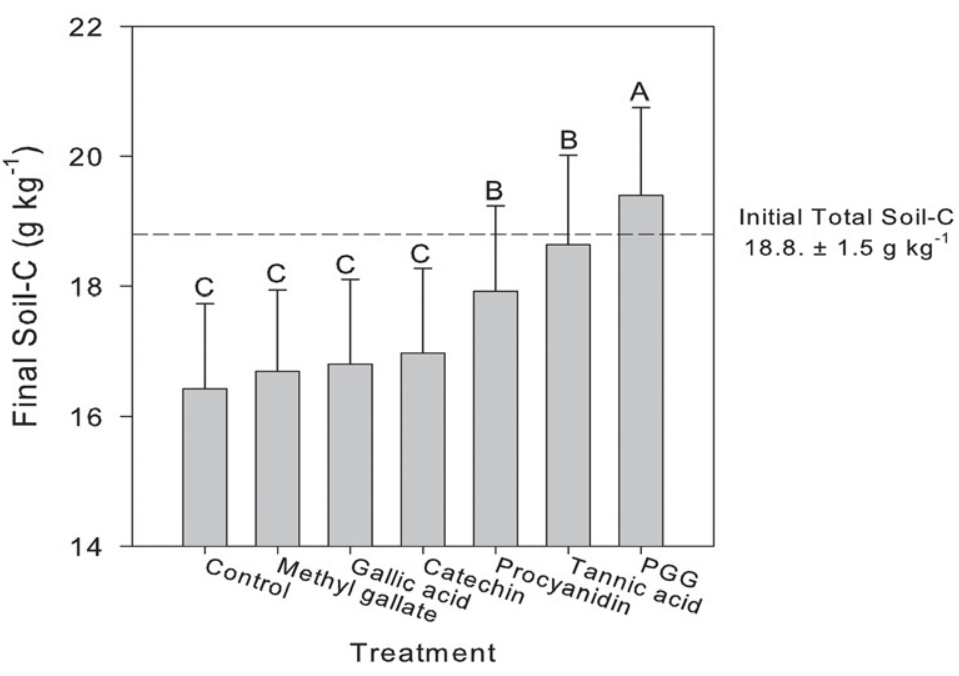

(b)

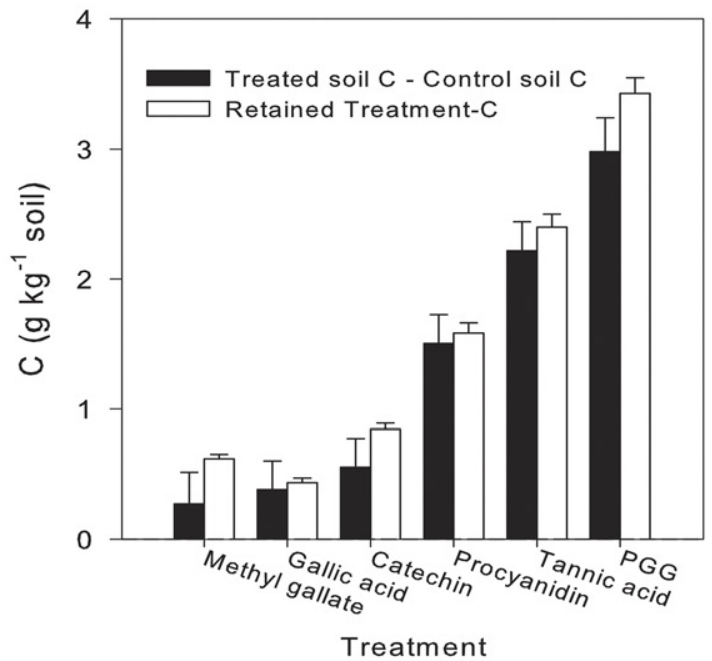

Fig. 4. (a) Main treatment effects on total soil C. Differences among treatments are denoted by letters (Mean, SEM, $n=66, P \leq 0.05$, Tukey's HSD) and (b) control corrected changes in total soil C (treated sample soil $C$ minus control sample soil C) compared to final sorption from Table 5 (Mean, SEM, $n=66$ ).

nificantly affected by the methyl gallate or catechin treatments but was decreased by the other treatments and especially by PGG. Treatment with PGG decreased soluble N by more than $20 \%$ in Mollisols to about $45 \%$ in Aridisols, equivalent to about 30 to $40 \mathrm{~kg}$ of soluble $\mathrm{N} \mathrm{ha}^{-1}$ in the 0 - to 10 -cm depth, assuming a soil bulk density of $1.3 \mathrm{Mg} \mathrm{m}^{-3}$. Main treatment effects on values of $\Delta$ Sol-N reflect the net sum of soluble $\mathrm{N}$ in treatment supernatants (Table 4) and extracted by the hot water incubation (Fig. 3). In the case of catechin, large differences from the water control did not result after either cool treatment step or subsequent hot extraction; consequently we conclude it does not interact with soil N. However, as observed in earlier work (Halvorson et al., 2012a, 2012b), methyl gallate increased extraction of soluble $\mathrm{N}$ in treatment supernatants but subsequently decreased hot water-extractable soluble $\mathrm{N}$, a pattern that implies it increases the efficacy of the initial extraction process. At this time, we do not have sufficient data to identify the mechanisms responsible for this increase of ef- ficacy but the combined net effect was not different from water. Alternatively, neither procyanidin or tannic acid initially affected soluble $\mathrm{N}$ (Table 4) but both compounds decreased soluble $\mathrm{N}$ extracted by hot water (Fig. 3 ) resulting in significantly less final soluble N. Finally, soluble $\mathrm{N}$ was decreased by gallic acid and PGG in both treatment supernatants and the hot water extracts. For most treatments, average values of $\Delta$ Sol-N were negatively and linearly related to retention of treatment $\mathrm{C}$ (Fig. 5a) suggesting a common mechanism for both. However, despite having the lowest retention by soil, gallic acid decreased soluble $\mathrm{N}$ to levels similar to tannic acid or PGG. We postulate that the decrease seen with gallic acid could be due, in part, to redox reactions with metals, especially Mn, in the soil (Halvorson et al., 2012b; Hem, 1965; Pohlman and McColl, 1989). Insoluble Mn(IV) could be reduced to the soluble $\mathrm{Mn}$ (II) as gallic acid oxidized to quinones and semi-quinones that formed "humic-like" polymers with amino-containing compounds and were retained in the soil matrix. However, this explanation cannot explain the lack of effect seen for catechin since it also reacts with soil metals and forms polymers (Chen et al., 2010).

The $\mathrm{T} \times \mathrm{S}$ interaction further revealed that unlike the other soil orders, soluble $\mathrm{N}$ was significantly decreased in Aridisols by all of the treatment compounds, including methyl gallate and gallic acid. In addition, significant differences among treatments were observed for most soil orders, especially in Mollisols and Ultisols. Formation of these soils typically results in strong patterns of horizonation. However, treatment effects on $\Delta$ Sol-N were relatively unvarying in Entisols, the soil order distinguished by a lack of profile development. This pattern suggests the effects of phenolic compounds on soluble $\mathrm{N}$ will vary with the age or composition of soil organic matter, or changes in chemical characteristics and physical properties with depth. Decreasing $\Delta$ Sol- $\mathrm{N}$ was also linearly related with increasing retention of treatment $\mathrm{C}$ for each individual soil order and appeared steepest for Ultisols, intermediate and similar for Alfisols and Mollisols and relatively shallow and similar for Entisols and Aridisols (Fig. 5b). These differences suggest that in addition to the amounts of treatment $\mathrm{C}$ retained, reductions in soluble $\mathrm{N}$ were influenced by soil properties such as $\mathrm{pH}$, EC, and/or CEC (Table 1). Although Ultisols contained intermediate amounts of organic matter compared to Entisols and Aridisols, they had significantly lower $\mathrm{pH}$, electrical conductivity, and CEC (Table 1). In addition, differences observed among soil orders could reflect variations in the chemical composition of soil organic matter associated with land use or pedogenic lineage. Halvorson et al. (2012b) found phenolic treatments reduced net soluble $\mathrm{N}$ in pasture soil significantly more than in soil from adjacent woodlands.

\section{Changes to Cation Exchange Capacity}

Treatment with water alone had little effect on soil CEC. The average CEC of control samples decreased by about 
$0.3 \mathrm{cmol}_{\mathrm{c}} \mathrm{kg}^{-1}$ soil or $4 \%$, compared to the initial value, $12.6 \pm 0.8 \mathrm{cmol}_{\mathrm{c}} \mathrm{kg}^{-1}$ soil (Tables 1 and 5). Net treatment effects $(\triangle \mathrm{CEC})$, determined with Eq. [4], varied strongly with treatment and as a $\mathrm{T} \times \mathrm{S}$ interaction $(P$ $\leq 0.001)$. The main effects of treatment showed nontannin phenolic compounds had no impact on soil CEC beyond that seen for the control. The Least Squares Means for $\triangle \mathrm{CEC}$, calculated for the gallic acid, methyl gallate, and catechin treatments, were not different from 0 (Table 5). Alternatively, significant net increases in soil CEC were observed for the tannin treatments, averaging about $1 \mathrm{cmol}_{\mathrm{c}} \mathrm{kg}^{-1}$ soil for both procyanidin and tannic acid, and about $2 \mathrm{cmol}_{\mathrm{c}} \mathrm{kg}^{-1}$ soil for PGG-treated samples or by about 8 and $16 \%$, respectively. Treatment effects on CEC and especially the differences between procyanidin and PGG have been hypothesized to relate to polarity, molecular shape, and additional substituents that contribute in specific ways unique to each compound (Halvorson et al., 2011). Because it is a nonpolar compound, PGG is thought to interact with the soil via hydrophobic interactions, while sorghum procyanidin is a polar compound and probably interacts by hydrogenbonding mechanisms (Hagerman et al., 1998). Different mechanisms of interaction with the soil may mask existing sites or present new sites for CEC depending on the surface chemistry of the soil and the amount of phenolic compound retained (Halvorson et al., 2011). The positive linear relationship between retention of treatment $\mathrm{C}$ and $\triangle \mathrm{CEC}$ (Fig. 6a) supports a hypothesis that additional exchange sites are formed.

The $\mathrm{T} \times \mathrm{S}$ interaction showed treatment effects on CEC were small and did not vary in Ultisols, whereas PGG increased $\triangle \mathrm{CEC}$ in all other soil orders. Though the effects of the other treatments were consistent among soil orders, PGG increased CEC more in Aridisols (44\%) than in Mollisols (11\%) or Ultisols (18\%). No treatment differences, observed in Ultisols, may relate to their weathered state, for example, clay mineralogy and $\mathrm{pH}$, and corresponded to a weak relationship between $\triangle \mathrm{CEC}$ and retention of treatment $\mathrm{C}$. The strongest linear increases in $\triangle \mathrm{CEC}$ with retained treatment $\mathrm{C}$ were observed for Aridisols and Entisols (Fig. 6b).

\section{CONCLUSIONS}

This study corroborated and expanded the results of our earlier limited work and we now generally conclude tannins entering soil are retained to a much greater degree than related phenolic compounds and significantly reduce the solubility of $\mathrm{N}$. Retention may be important on a landscape scale and be linked to patterns of soil organic matter or texture while tannin effects related to nutrient cycling such as increased CEC, immobilization of soil N, or interactions with soil toxicants (Kinraide and Hagerman, 2010) may be of greatest significance in the vicinity of plant roots. Retention of plant phenolics, added by leaching or from plant residues, represents a relatively rapid incorporation of
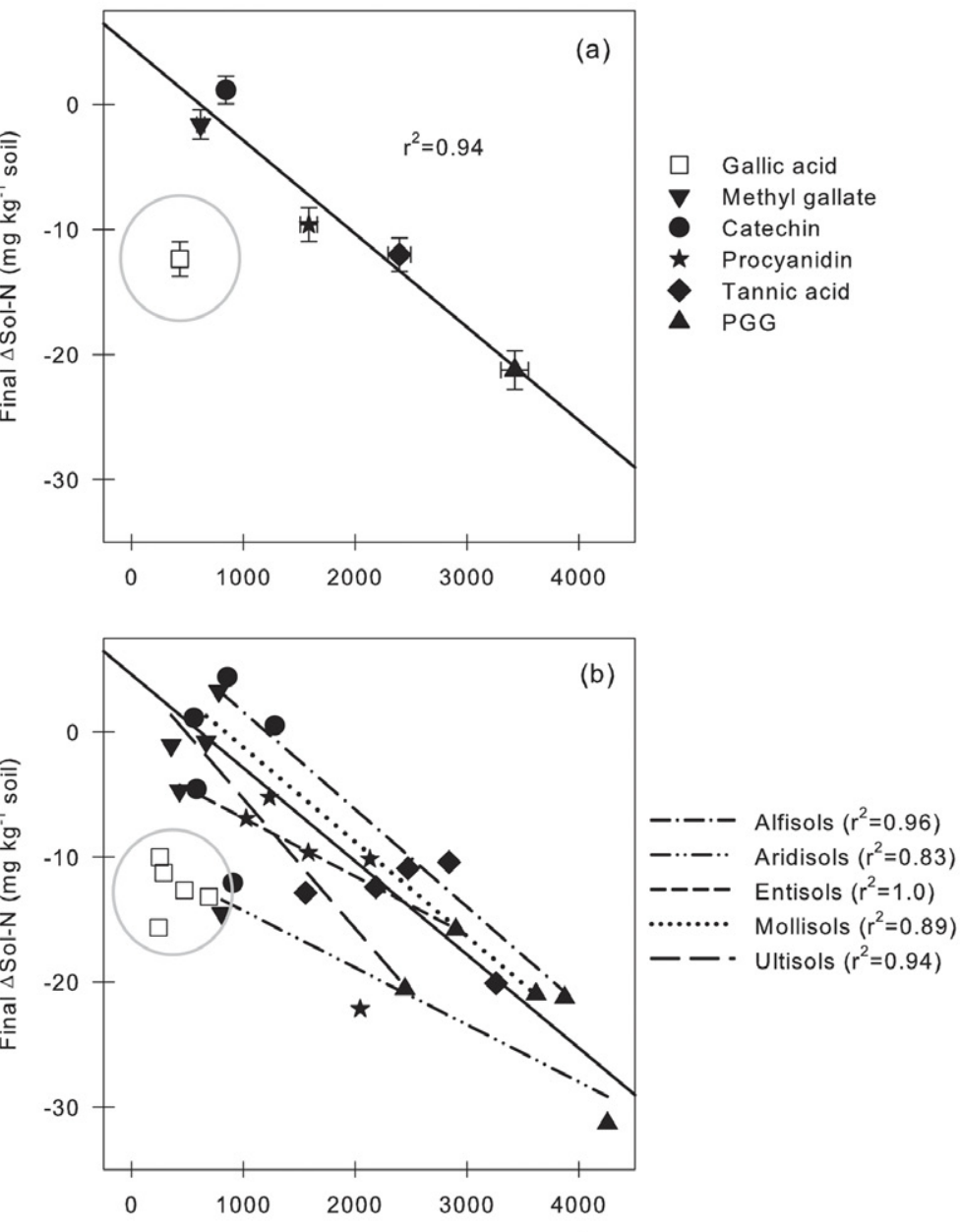

Final retention of treatment-C $\left(\mathrm{mg} \mathrm{kg}^{-1}\right.$ soil)

Fig. 5. (a) Main effects of $\Delta$ Sol-N plotted against retained treatment C (Mean, SEM, $n=66$ ) and (b) $\Delta$ Sol-N plotted against retained treatment $C$ for individual soil orders. Data for gallic acid (circled) were omitted from the linear regressions.

organic matter to soil. However, little is known about the consequences of microbiological degradation or the chemical transformations that occur once they enter soil, or interactions with other forms of soil organic matter (cf. Kögel-Knabner, 2002; Rovira and Vallejo, 2002). Immobilization of organic soil $\mathrm{N}$ by tannins, presumably through the formation of complexes, has not been well studied in agricultural soils and could be a useful means for managing soil fertility providing nutrient uptake by crops or root functions are not inhibited.

That no single soil attribute explained the patterns of tannin retention or decreased $\mathrm{N}$ solubility suggests both are influenced by compound specific characteristics such as molecular size, polarity, and configuration and involve several mechanisms. The differences observed among soil orders suggest that the magnitude and consequences of tannin effects will covary across the landscape together with patterns of attributes that reflect soil-forming processes including management. Besides a central conceptual theme, our use of soil orders provides a geo-referenced context with which to develop future research by identifying the distribution of soil types or suites of soil characteristics that would be likely to respond to tannins. In this study, tannin effects were especially evident in 

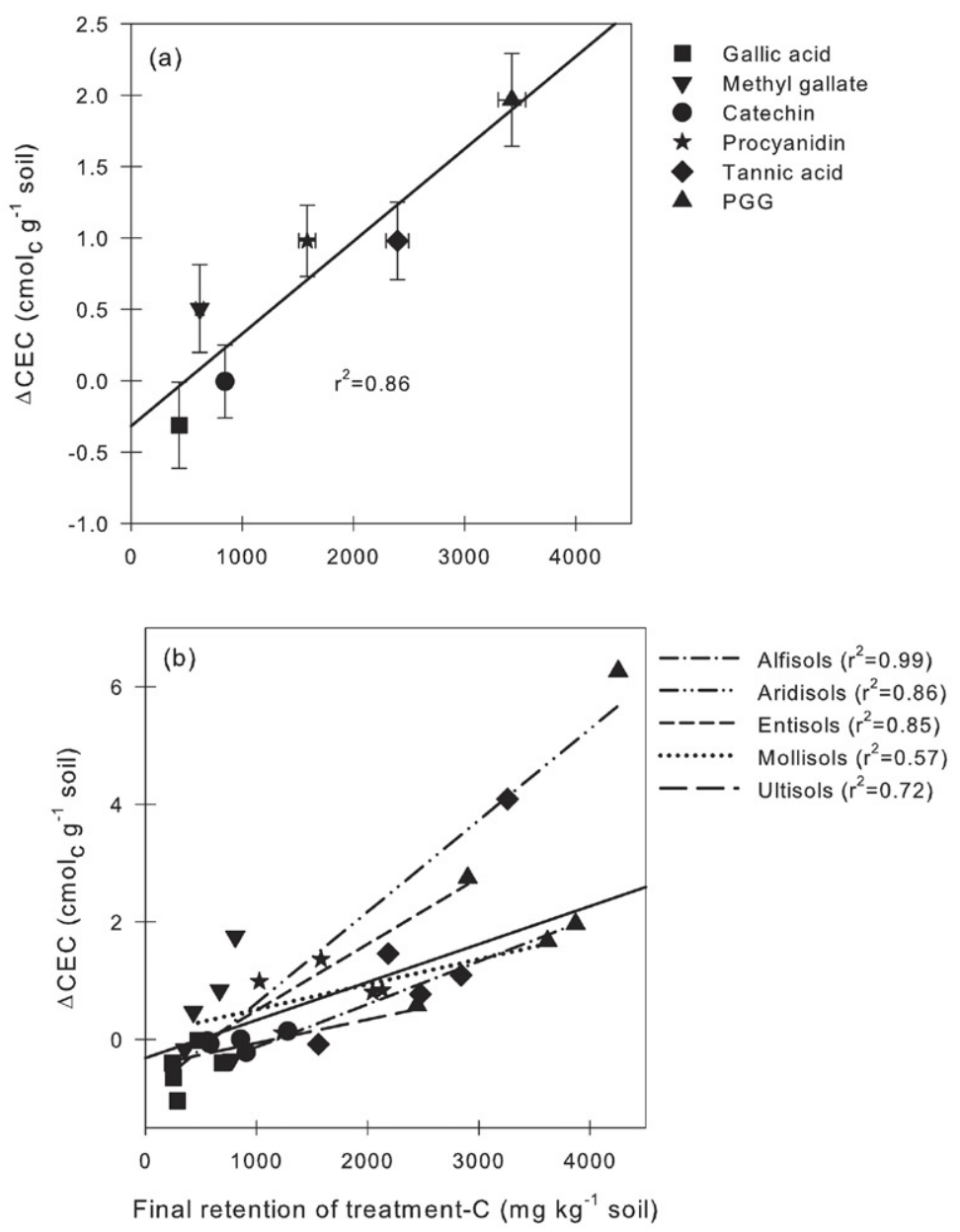

Fig. 6. (a) Main effects of $\triangle \mathrm{CEC}$ plotted against retained treatment $\mathrm{C}$ (Mean, SEM, $n=66$ ) and (b) $\triangle$ CEC plotted against retained treatment $C$ for individual soil orders.

Appendix A. Selected soil properties for individual samples.

\begin{tabular}{|c|c|c|c|c|c|c|c|c|c|c|c|c|c|}
\hline Contactt & $\begin{array}{c}\text { State/ } \\
\text { Province }\end{array}$ & $\begin{array}{l}\text { Lat. (North)/ } \\
\text { Long. (West) }\end{array}$ & $\begin{array}{l}\text { Soil } \\
\text { order }\end{array}$ & Management $\ddagger$ & Sand & Silt & Clay & $\mathrm{pH}$ & $\begin{array}{l}\text { Total } \\
\text { soil C }\end{array}$ & $\begin{array}{c}\text { Organic } \\
\text { soil C }\end{array}$ & $\begin{array}{l}\text { Total } \\
\text { soil N }\end{array}$ & EC§ & CEC \\
\hline & & & & & 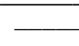 & $-\%$ & 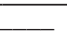 & & - & $-\mathrm{g} \mathrm{kg}^{-1}$ & - & $\mu \mathrm{S} \mathrm{m}^{-1}$ & $\mathrm{cmolc} \mathrm{kg}^{-1}$ \\
\hline Acosta-Martinez & TX & $33.68 / 101.77$ & Mollisol & $\mathrm{CT}$, cotton-sorghum & 50 & 32 & 18 & 7.57 & 4.54 & 4.55 & 0.44 & 169 & 11.8 \\
\hline Acosta-Martinez & $\mathrm{TX}$ & $33.68 / 101.77$ & Mollisol & $\mathrm{CT}$, continuous cotton & 54 & 28 & 18 & 7.38 & 3.90 & 3.60 & 0.43 & 181 & 10.5 \\
\hline Acosta-Martinez & TX & $33.68 / 101.77$ & Mollisol & NT, cotton-sorghum & 48 & 32 & 20 & 7.81 & 5.17 & 5.15 & 0.53 & 192 & 12.0 \\
\hline Arriaga & $\mathrm{AL}$ & $32.43 / 85.89$ & Ultisol & $\mathrm{CT}$, cotton-corn & 75 & 19 & 6 & 6.37 & 5.44 & 5.03 & 0.45 & 125 & 1.9 \\
\hline Arriaga & $\mathrm{AL}$ & $32.43 / 85.89$ & Ultisol & CsT., cotton-corn & 75 & 23 & 2 & 6.54 & 7.78 & 7.27 & 0.60 & 75.1 & 2.2 \\
\hline Arriaga & $\mathrm{AL}$ & $32.42 / 85.90$ & Ultisol & $\mathrm{CT}$, cotton-corn & 48 & 34 & 18 & 5.79 & 8.16 & 8.03 & 0.85 & 171 & 4.4 \\
\hline Arriaga & $\mathrm{AL}$ & $32.42 / 85.90$ & Ultisol & $\mathrm{CT}+\mathrm{M}$, cotton-corn & 48 & 34 & 18 & 5.69 & 12.98 & 11.89 & 1.24 & 419 & 5.1 \\
\hline Baker. & $M N$ & $44.75 / 93.07$ & Mollisol & CT, corn-soybean & 20 & 62 & 18 & 6.07 & 22.22 & 21.52 & 1.87 & 319 & 17.3 \\
\hline Baker. & MN & $44.75 / 93.07$ & Mollisol & ST, corn-soybean & 22 & 62 & 16 & 6.09 & 27.17 & 25.29 & 2.25 & 351 & 19.1 \\
\hline Busscher & SC & $34.29 / 79.75$ & Ultisol & CsT, corn-wheat & 66 & 28 & 6 & 7.35 & 12.43 & 10.13 & 1.04 & 72.8 & 4.9 \\
\hline Busscher & SC & $34.29 / 79.75$ & Ultisol & $\mathrm{CT}$, corn-wheat & 70 & 22 & 8 & 6.22 & 9.89 & 9.28 & 0.79 & 68.5 & 2.7 \\
\hline Emmerich & $A Z$ & $31.74 / 109.94$ & Entisol & UC, G, grass under trees & 75 & 13 & 12 & 8.13 & 6.54 & 6.04 & 0.74 & 131 & 9.8 \\
\hline Emmerich & $A Z$ & $31.74 / 109.94$ & Entisol & UC, G, grass & 72 & 16 & 12 & 8.43 & 12.68 & 7.80 & 0.82 & 203 & 16.7 \\
\hline Emmerich & $A Z$ & $31.74 / 110.05$ & Aridisol & UC, G, grass, high $\mathrm{CaCO}_{3}$ & 50 & 30 & 20 & 8.35 & 64.64 & 12.94 & 1.55 & 203 & 13.0 \\
\hline Follett & $\mathrm{CO}$ & $40.32 / 103.15$ & Mollisol & NT, wheat-fallow & 22 & 60 & 18 & 5.73 & 11.22 & 9.88 & 1.26 & 407 & 11.6 \\
\hline Follett & $\mathrm{CO}$ & $40.32 / 103.15$ & Mollisol & $\mathrm{CT}$, wheat-fallow & 24 & 60 & 16 & 6.47 & 7.46 & 7.06 & 0.89 & 281 & 12.8 \\
\hline Follett & $\mathrm{CO}$ & $40.32 / 103.15$ & Mollisol & $\mathrm{CT}$, continuous corn & 24 & 58 & 18 & 5.67 & 10.73 & 10.22 & 1.20 & 368 & 11.6 \\
\hline Follett & ID & $43.52 / 111.48$ & Mollisol & NT, continuous wheat & 10 & 76 & 14 & 7.35 & 19.24 & 18.60 & 1.94 & 571 & 18.1 \\
\hline Follett & ID & $43.52 / 111.48$ & Mollisol & CT, continuous wheat & 10 & 76 & 14 & 7.98 & 11.71 & 10.56 & 1.25 & 305 & 16.8 \\
\hline
\end{tabular}

Aridisols, the soil order with highest average $\mathrm{pH}$ and inorganic $\mathrm{C}$ but were lowest in Ultisols characterized by relatively low $\mathrm{pH}$, high amounts of sand and low CEC (Table 1).

Further efforts are needed to extend the results of our studies to supplement the limited information about tannin-soil interactions and to determine their utility at the field scale for achieving specific soil management goals. This will be aided by new methods that can determine the quantity or composition of phenolic plant secondary compounds in soil as well as identification of useful functional classes of tannins and related phenolic compounds. Tannins may be part of management strategies that intensify productivity of sustainable systems (Herrero et al., 2010; Tilman et al., 2011), play a role during transition from one management to another, or as part of efforts to improve or remediate soil ecosystem services (Robinson et al., 2013). However, additional work is needed to devise and evaluate cost effective strategies to incorporate desirable phenolic compounds into agroecosystems. One option might be through selection of crop rotations or pasture forage mixtures able to add useful polyphenolic compounds to the soil directly with residues or indirectly by through livestock feeding. The livestock-soil linkage may be especially attractive if the benefits that dietary tannins may confer to ruminant physiology, such an improvement of $\mathrm{N}$ use efficiency (McSweeney et al., 2001; Min et al., 2003), and reduction of greenhouse gas formation (e.g., Eckard et al., 2010; Goel and Makkar, 2012; McAllister et al., 2011) can be married to the emerging research that show how tannins affect the 


\begin{tabular}{|c|c|c|c|c|c|c|c|c|c|c|c|c|c|}
\hline Contactt & $\begin{array}{l}\text { State/ } \\
\text { Province }\end{array}$ & $\begin{array}{l}\text { Lat. (North)/ } \\
\text { Long. (West) }\end{array}$ & $\begin{array}{l}\text { Soil } \\
\text { order }\end{array}$ & Management $\ddagger$ & Sand & Silt & Clay & $\mathrm{pH}$ & $\begin{array}{l}\text { Total } \\
\text { soil C }\end{array}$ & $\begin{array}{c}\text { Organic } \\
\text { soil C }\end{array}$ & $\begin{array}{l}\text { Total } \\
\text { soil } \mathrm{N}\end{array}$ & EC§ & CEC \\
\hline & & & & & \multicolumn{3}{|c|}{$\%$} & & \multicolumn{3}{|c|}{$-\mathrm{g} \mathrm{kg}^{-1}-$} & $\mu S m^{-1}$ & $\mathrm{cmolc} \mathrm{kg}^{-1}$ \\
\hline Follett & ID & $43.52 / 111.48$ & Mollisol & UC, UG & 22 & 70 & 8 & 7.70 & 37.76 & 32.73 & 2.86 & 488 & 20.5 \\
\hline Follett & VA & $37.52 / 76.85$ & Ultisol & $\mathrm{CT}$, corn-sorghum & 79 & 13 & 8 & 6.20 & 6.70 & 6.02 & 0.64 & 78.3 & 1.7 \\
\hline Follett & VA & $37.62 / 77.11$ & Ultisol & NT, corn-sorghum & 89 & 7 & 4 & 5.91 & 9.06 & 8.27 & 0.80 & 140 & 2.3 \\
\hline Follett & $\mathrm{NE}$ & $41.22 / 102.98$ & Mollisol & CT, wheat-fallow & 30 & 54 & 16 & 6.99 & 14.15 & 14.04 & 1.45 & 854 & 17.7 \\
\hline Follett & NE & $41.22 / 102.98$ & Mollisol & NT, wheat-fallow & 22 & 58 & 20 & 6.70 & 23.05 & 22.71 & 2.17 & 459 & 24.1 \\
\hline Franzluebbers & GA & $33.87 / 83.42$ & Ultisol & UC, G, inorganic fertilizer & 62 & 28 & 10 & 5.95 & 12.67 & 11.46 & 1.12 & 112 & 2.9 \\
\hline Franzluebbers & GA & $33.87 / 83.42$ & Ultisol & UC, G, broiler litter fert. & 68 & 14 & 18 & 5.71 & 19.34 & 18.30 & 1.83 & 232 & 4.0 \\
\hline Gollany & OR & $45.72 / 118.63$ & Mollisol & $\mathrm{CT}, \mathrm{M}$, wheat-fallow & 26 & 62 & 12 & 7.84 & 14.07 & 14.06 & 1.30 & 172 & 16.8 \\
\hline Gollany & OR & $45.72 / 118.63$ & Mollisol & CT, wheat-fallow & 24 & 64 & 12 & 6.65 & 10.51 & 10.45 & 0.82 & 93.8 & 12.7 \\
\hline Gollany & OR & $45.72 / 118.63$ & Mollisol & $\mathrm{CT}, \mathrm{B}$, wheat-fallow & 28 & 60 & 12 & 6.31 & 9.57 & 9.52 & 0.70 & 84.3 & 13.0 \\
\hline Gregorich & ON & $45.37 / 75.73$ & Mollisol & NT, continuous corn & 60 & 32 & 8 & 7.30 & 18.51 & 18.09 & 1.57 & 339 & 10.9 \\
\hline Gregorich & ON & $45.37 / 75.73$ & Mollisol & $\mathrm{CT}$, continuous corn & 64 & 32 & 4 & 6.35 & 19.60 & 18.02 & 1.85 & 462 & 9.4 \\
\hline Halvorson. & WV & $37.83 / 80.72$ & Alfisol & UC, G, pasture & 40 & 48 & 12 & 5.71 & 24.44 & 24.09 & 2.32 & 91 & 6.9 \\
\hline Halvorson. & WV & $37.83 / 80.72$ & Alfisol & UC, UG, oak trees & 36 & 44 & 20 & 4.35 & 37.42 & 36.04 & 2.15 & 82.4 & 5.7 \\
\hline Herrick & NM & $32.57 / 106.6$ & Aridisol & UC, UG & 54 & 38 & 8 & 8.40 & 31.60 & 7.39 & 0.94 & 176 & 11.1 \\
\hline Herrick & NM & $32.57 / 106.6$ & Aridisol & UC, UG & 56 & 36 & 8 & 8.38 & 35.53 & 9.48 & 1.11 & 187 & 10.9 \\
\hline Koehn & ID & $42.52 / 114.38$ & Aridisol & $\mathrm{CT}$, corn rotation & 18 & 68 & 14 & 8.43 & 18.51 & 8.26 & 1.06 & 396 & 18.5 \\
\hline Koehn & ID & $42.52 / 114.38$ & Aridisol & as above $w /$ compost & 20 & 68 & 12 & 8.44 & 32.66 & 16.35 & 1.83 & 571 & 18.2 \\
\hline Laird & $\mathrm{IA}$ & $42.02 / 93.76$ & Mollisol & $\mathrm{CT}$, corn-soybean & 40 & 40 & 20 & 6.34 & 25.23 & 23.38 & 2.05 & 271 & 22.8 \\
\hline Laird & IA & $42.02 / 93.76$ & Mollisol & NT, corn-soybean & 46 & 36 & 18 & 6.19 & 21.15 & 19.49 & 1.78 & 184 & 17.0 \\
\hline Lerch & $\mathrm{MO}$ & $39.23 / 92.12$ & Alfisol & CsT, corn-soybean & 10 & 62 & 28 & 6.96 & 13.14 & 12.56 & 1.32 & 257 & 16.7 \\
\hline Lerch & $\mathrm{MO}$ & $39.23 / 92.12$ & Alfisol & NT, corn-soybean & 12 & 58 & 30 & 6.53 & 13.27 & 13.02 & 1.45 & 297 & 18.2 \\
\hline Lerch. & $\mathrm{MO}$ & $39.23 / 92.12$ & Alfisol & UC, UG & 14 & 66 & 20 & 7.21 & 20.32 & 17.90 & 1.79 & 250 & 14.0 \\
\hline Liebig & ND & 46.77/100.92 & Mollisol & G, crested wheatgrass & 36 & 52 & 12 & 5.50 & 39.04 & 37.15 & 3.69 & 203 & 17.5 \\
\hline Liebig & ND & 46.77/100.92 & Mollisol & $\mathrm{G}$, native, heavily grazed & 40 & 52 & 8 & 6.68 & 47.99 & 45.96 & 3.95 & 182 & 23.1 \\
\hline Liebig & ND & $46.77 / 100.92$ & Mollisol & $\mathrm{G}$, native, mod, grazed & 34 & 58 & 8 & 6.31 & 43.74 & 42.19 & 3.65 & 156 & 20.6 \\
\hline McLain & $A Z$ & $31.81 / 110.89$ & Entisol & UC, UG & 62 & 28 & 10 & 8.64 & 6.54 & 3.74 & 0.57 & 863 & 10.5 \\
\hline McLain & $\mathrm{AZ}$ & $31.81 / 110.89$ & Entisol & UC, G & 64 & 28 & 8 & 8.51 & 8.94 & 7.55 & 0.77 & 300 & 10.4 \\
\hline Morgan & WY & $40.82 / 104.77$ & Mollisol & UC, G & 70 & 18 & 12 & 6.41 & 12.93 & 11.58 & 1.13 & 120 & 10.0 \\
\hline Morgan & WY & $40.82 / 104.77$ & Mollisol & UC, UG & 66 & 24 & 10 & 6.29 & 26.57 & 23.74 & 2.03 & 142 & 10.7 \\
\hline Pote & $\mathrm{AR}$ & $35.07 / 93.99$ & Ultisol & UC, G, grass & 38 & 54 & 8 & 5.95 & 18.40 & 16.54 & 1.74 & 96.7 & 5.5 \\
\hline Pote & $\mathrm{AR}$ & $35.07 / 93.99$ & Ultisol & UC, G, loblolly pine & 38 & 54 & 8 & 5.10 & 15.49 & 16.83 & 1.36 & 62 & 3.8 \\
\hline Sanderson, M. & PA & $40.72 / 77.94$ & Alfisol & $\mathrm{CT}$, corn rotation & 20 & 54 & 26 & 6.59 & 15.79 & 15.97 & 1.53 & 178 & 9.7 \\
\hline Sanderson, $\mathrm{M}$. & PA & $40.72 / 77.94$ & Alfisol & UC, big bluestem & 24 & 50 & 26 & 6.08 & 23.46 & 23.07 & 1.90 & 128 & 9.8 \\
\hline Sistani & KY & $36.56 / 86.28$ & Alfisol & $\mathrm{CT}$, continuous corn & 8 & 64 & 28 & 7.15 & 11.34 & 11.45 & 1.24 & 142 & 11.9 \\
\hline Sistani & KY & $36.56 / 86.28$ & Alfisol & as above w/poultry litter & 10 & 64 & 26 & 6.78 & 17.78 & 17.11 & 2.31 & 700 & 14.1 \\
\hline Smith, D & IN & $40.30 / 86.90$ & Mollisol & $\mathrm{CT}$, continuous corn & 20 & 58 & 22 & 6.97 & 21.00 & 20.41 & 1.88 & 319 & 15.2 \\
\hline Smith, D & IN & $40.30 / 86.90$ & Mollisol & NT, sorghum sudangrass & 54 & 36 & 10 & 6.88 & 27.44 & 26.02 & 2.25 & 84 & 10.0 \\
\hline Smith, D & IN & $40.50 / 87.00$ & Mollisol & $\mathrm{CT}$, continuous corn & 22 & 52 & 26 & 6.07 & 31.03 & 28.59 & 2.15 & 205 & 25.0 \\
\hline Smith, D & IN & $40.50 / 87.00$ & Mollisol & $\mathrm{CT}, \mathrm{M}$, continuous corn & 22 & 50 & 28 & 6.49 & 28.75 & 27.38 & 2.41 & 553 & 26.5 \\
\hline $\begin{array}{l}\text { Smith, J } \\
\text { Smith, J }\end{array}$ & $\begin{array}{l}\text { WA } \\
\text { WA }\end{array}$ & $\begin{array}{l}46.76 / 117.19 \\
46.76 / 117.19\end{array}$ & $\begin{array}{l}\text { Mollisol } \\
\text { Mollisol }\end{array}$ & $\begin{array}{l}\mathrm{CT} \text {, continuous wheat } \\
\mathrm{NT} \text {, continuous wheat }\end{array}$ & $\begin{array}{l}20 \\
22\end{array}$ & $\begin{array}{l}70 \\
64\end{array}$ & $\begin{array}{l}10 \\
14\end{array}$ & $\begin{array}{l}5.42 \\
5.06\end{array}$ & $\begin{array}{l}32.19 \\
28.21\end{array}$ & $\begin{array}{l}31.35 \\
26.82\end{array}$ & $\begin{array}{l}2.56 \\
2.19\end{array}$ & $\begin{array}{l}471 \\
328\end{array}$ & $\begin{array}{l}13.1 \\
11.8\end{array}$ \\
\hline Steenwerth & CA & $38.53 / 121.79$ & Entisol & CsT, vineyard & 48 & 38 & 14 & 7.08 & 9.83 & 8.70 & 0.94 & 199 & 18.9 \\
\hline Steenwerth & CA & $38.53 / 121.79$ & Entisol & CsT, vineyard berm & 52 & 34 & 14 & 7.28 & 7.54 & 6.74 & 0.86 & 256 & 18.0 \\
\hline Zibilski & TX & $26.43 / 97.95$ & Alfisol & $\mathrm{CT}$, vegetables & 84 & 10 & 6 & 7.02 & 3.53 & 3.00 & 0.36 & 124 & 5.0 \\
\hline Zibilski & $\mathrm{TX}$ & $26.22 / 97.99$ & Mollisol & $\mathrm{CT}$, vegetables & 54 & 22 & 24 & 8.67 & 14.47 & 7.54 & 0.72 & 315 & 14.6 \\
\hline Zibilski. & $\mathrm{TX}$ & $26.14 / 97.96$ & Mollisol & $\mathrm{CT}$, grapefruit & 50 & 16 & 34 & 8.56 & 19.16 & 8.78 & 0.96 & 245 & 20.7 \\
\hline
\end{tabular}

† Veronica Acosta-Martinez, vacostam@lbk.ars.usda.gov; Francisco J. Arriaga, farriaga@msa-stoneville.ars.usda.gov; John Baker, John.Baker@ars.usda.gov; Warren J. Busscher, Warren.Busscher@ars.usda.gov; William Emmerich, bemmerich@tucson.ars.ag.gov; Ronald F. Follett, ronald.follett@ars.usda.gov; Alan J. Franzluebbers Alan.Franzluebbers@ars.usda.gov; Hero T. Gollany, hero.gollany@oregonstate.edu; Ed Gregorich, gregoriche@agr.gc.ca; Jeffrey E. Herrick, jherrick@nmsu.edu; Anita C. Koehn, akoehn@nwisrl.ars.usda.gov; David A. Laird, laird@nstl.gov; Robert N. Lerch, Bob.Lerch@ARS.USDA. GOV; Mark A. Liebig, mark.liebig@ars.usda.gov; Jean McLain, jmclain@uswcl.ars.ag.gov; Jack A. Morgan, jack.morgan@ars.usda.gov; Daniel H. Pote, dpote@spa.ars.usda.gov; Matt A. Sanderson, matt.sanderson@ars.usda.gov; Karamat R. Sistani, ksistani@ars.usda.gov; Jeffrey L. Smith, jlsmith@mail. wsu.edu; Kerri Steenwerth, ksteenwerth@ucdavis.edu; Larry M. Zibilske, Izibilske@weslaco.ars.usda.gov

₹ CT, conventional tillage leaving $<30 \%$ residue cover; $\mathrm{CsT}$, conservation tillage leaving $>30 \%$ residue cover; NT, no-tillage; $\mathrm{M}$, manure added; ST, strip tillage; UC, uncropped; UG, ungrazed; B, residue burned off.

$\S \mathrm{EC}=$ electrical conductance; $\mathrm{CEC}=$ cation exchange capacity. 
composition and characteristics of animal waste (Powell et al., 2011; Powell and Broderick, 2011).

\section{ACKNOWLEDGMENTS}

The authors gratefully acknowledge numerous colleagues located throughout the United States and Canada who kindly supplied samples for analysis. The authors also thank J. Harrah, R. Kohlberg, and T. Robertson for analysis of data and Dr. M. Schmidt for several useful discussions. This work is dedicated to PQH.

\section{REFERENCES}

Adamczyk, B., S. Adamczyk, A. Smolander, and V. Kitunen. 2011. Tannic acid and Norway spruce condensed tannins can precipitate various organic nitrogen compounds. Soil Biol.Biochem.43:628-637.doi:10.1016/j.soilbio.2010.11.034

Adamczyk, B., V. Kitunen, and A. Smolander. 2013. Response of soil C and N transformations to condensed tannins and different organic N-condensed tannin complexes. Applied Soil Ecology 64:163-170. doi: 10.1016/j. apsoil.2012.12.003.

Cesco, S., T. Mimmo, G. Tonon, N. Tomasi, R. Pinton, R. Terzano et al. 2012. Plant-borne flavonoids released into the rhizosphere: Impact on soil bioactivities related to plant nutrition. A review. Biol. Fertil. Soils 48:123149. doi:10.1007/s00374-011-0653-2

Chen, D., W. Xie, D. Luo, and G. Song. 2009. Characteristics of soil organic matter and sorption of phenanthrene, naphthalene 1,3,5-TCB and o-xylene. Soil and Sediment Contamination. Int. J. 18:229-241.

Chen, Y.M., T.M. Tsao, C.C. Liu, P.M. Huang, and M.K. Wang. 2010. Polymerization of catechin catalyzed by $\mathrm{Mn}$-, $\mathrm{Fe}$-and $\mathrm{Al}$-oxides. Colloids and Surfaces B: Biointerfaces 81:217-223. doi: 10.1016/j.colsurfb.2010.07.012.

Ciesielski, H., and T. Sterckeman. 1997a. A comparison between three methods for the determination of cation exchange capacity and exchangeable cations in soils. Agronomie 17:9-16. doi:10.1051/agro:19970102

Ciesielski, H., and T. Sterckeman. 1997b. Determination of cation exchange capacity and exchangeable cations in soils by means of cobalt hexamine trichloride. Effects of experimental conditions. Agronomie 17:1-7. doi:10.1051/agro: 19970101

Coq, S., J.M. Souquet, E. Meudec, V. Cheynier, and S. Hattenschwiler. 2010. Interspecific variation in leaf litter tannins drives decomposition in a tropical rain forest of French Guiana. Ecology 91:2080-2091. doi:10.1890/09-1076.1

Curtin, D., C.E. Wright, M.H. Beare, and F.M. McCallum. 2006. Hot waterextractable nitrogen as an indicator of soil nitrogen availability. Soil Sci. Soc. Am. J. 70:1512-1521. doi:10.2136/sssaj2005.0338

Dominati, E., M. Patterson, and A. Mackay. 2010. A framework for classifying and quantifying the natural capital and ecosystem services of soils. Ecological Economics 69:1858-1868. doi: 10.1016/j.ecolecon.2010.05.002.

Eckard, R.J., C. Grainger, and C.A.M. de Klein. 2010. Options for the abatement of methane and nitrous oxide from ruminant production: A review. Livest. Sci. 130:47-56. doi:10.1016/j.livsci.2010.02.010

Fabre, V.E., M.B. Bizzotto, and J.C. Tirner. 2010. Comportamiento Resistente de Suelos Orgánicos Estabilizados con Tanino. Información tecnológica 21:103-112.

Feldman, K.S., and R.S. Smith. 1996. Ellagitannin chemistry. First total synthesis of the 2,3- and 4,6-coupled ellagitannin pedunculagin. J. Org. Chem. 61:2606-2612. doi:10.1021/jo952130+

Friedman, M., and H.S. Jürgens. 2000. Effect of $\mathrm{pH}$ on the stability of plant phenolic compounds. J. Agric. Food Chem. 48:2101-2110. doi:10.1021/jf990489j

Gallet, C., and P. Lebreton. 1995. Evolution of phenolic patterns in plants and associated litters and humus of a mountain forest ecosystem. Soil Biol. Biochem. 27:157-165. doi:10.1016/0038-0717(94)00167-Y

Ghani, A., M. Dexter, and K.W. Perrott. 2003. Hot-water extractable carbon in soils: A sensitive measurement for determining impacts of fertilisation, grazing and cultivation. Soil Biol. Biochem. 35:1231-1243. doi:10.1016/ S0038-0717(03)00186-X

Goel, G., and H. Makkar. 2012. Methane mitigation from ruminants using tannins and saponins. Trop. Anim. Health Prod. 44:729-739. doi:10.1007/s11250-011-9966-2

Graham, H.D. 1992. Stabilization of the Prussian blue color in the determination of polyphenols. J. Agric. Food Chem. 40:801-805. doi:10.1021/jf00017a018
Hagerman, A.E. 2002. Tannin handbook. Miami Univ., Oxford OH. www.users. muohio.edu/hagermae/ (accessed December 2007).

Hagerman, A.E. 2012. Fifty years of polyphenol-protein complexes. In: V. Cheyneir, P. Sarni-Manchado, and S. Quideau, editors, Recent advances in polyphenol research. Wiley-Blackwell, London. p. 71-91.

Hagerman, A.E., and L.G. Butler. 1981. The specificity of proanthocyanidinprotein interactions. J. Biol. Chem. 256:4494-4497.

Hagerman, A.E., M.E. Rice, and N.T. Ritchard. 1998. Mechanisms of protein precipitation for two tannins, pentagalloyl glucose and epicatechin 16 $(4 \rightarrow 8)$ catechin (Procyanidin). J. Agric. Food Chem. 46:2590-2595. doi:10.1021/jf971097k

Halvorson, J.J., H.T. Gollany, A.C. Kennedy, A.E. Hagerman, J.M. Gonzalez, and S.B. Wuest. 2012a. Sorption of tannin and related phenolic compounds and effects on extraction of soluble- $\mathrm{N}$ in soil amended with several carbon sources. Agriculture (Basel) 2:52-72. doi:10.3390/agriculture2010052

Halvorson, J.J., and J.M. Gonzalez. 2008. Tannic acid reduces recovery of watersoluble carbon and nitrogen from soil and affects the composition of Bradford-reactive soil protein. Soil Biol. Biochem. 40:186-197. doi:10.1016/j. soilbio.2007.07.022

Halvorson, J.J., J.M. Gonzalez, and A.E. Hagerman. 2011. Repeated applications of tannins and related phenolic compounds are retained by soil and affect cation exchange capacity. Soil Biol. Biochem. 43:1139-1147. doi:10.1016/j.soilbio.2011.01.023

Halvorson, J.J., J.M. Gonzalez, and A.E. Hagerman. 2012b. Changes in soluble- $\mathrm{N}$ in forest and pasture soils after repeated applications of tannins and related phenolic compounds. Int. J. Agron. 2012:1-13. doi: $10.1155 / 2012 / 163054$

Halvorson, J.J., J.M. Gonzalez, A.E. Hagerman, and J.L. Smith. 2009. Sorption of tannin and related phenolic compounds and effects on soluble-N in soil. Soil Biology \& Biochemistry 41:2002-2010. doi: 10.1016/j.soilbio.2009.07.006.

Haslam, E. 1981. Vegetable tannins. In: E.E. Conn, editor, The biochemistry of plants. Secondary plant products. Vol. 7. Academic Press, New York. p. 527-556.

Hättenschwiler, S., and P.M. Vitousek. 2000. The role of polyphenols in terrestrial ecosystem nutrient cycling. Trends Ecol. Evol. 15:238-243. doi:10.1016/ S0169-5347(00)01861-9

Hem, J.D. 1965. Reduction and complexing of manganese by gallic acids. U.S. Gov. Print. Office, Washington, DC.

Herrero, M., P.K. Thornton, A.M. Notenbaert, S. Wood, S. Msangi, H.A. Freeman et al. 2010. Smart investments in sustainable food production: Revisiting mixed crop-livestock systems. Science (Washington, DC) 327:822-825. doi:10.1126/science. 1183725

Horner, J.D., J.R. Gosz, and R.G. Cates. 1988. The role of carbon-based plant secondary metabolites in decomposition in terrestrial ecosystems. Am. Nat. 132:869-883. doi:10.1086/284894

ISO 23470:2007. 2007. Soil quality- Determination of effective cation exchange capacity (CEC) and exchangeable cations using a hexamminecobalt trichloride solution. ISO/TC 190, Soil quality Subcommitte SC3, Chemical methods and soil characteristics.

Jenny, H. 1941. Factors of soil formation. McGraw-Hill, New York.

Kaal, J., K.G.J. Nierop, and J.M. Verstraten. 2005. Retention of tannic acid and condensed tannin by Fe-oxide-coated quartz sand. J. Colloid Interface Sci. 287:72-79. doi:10.1016/j.jcis.2005.01.104

Karickhoff, S.W., D.S. Brown, and T.A. Scott. 1979. Sorption of hydrophobic pollutants on natural sediments. Water Research 13:241-248. doi: 10.1016/0043-1354(79)90201-x.

Kinraide, T.B., and A.E. Hagerman. 2010. Interactive intoxicating and ameliorating effects of tannic acid, aluminum $\left(\mathrm{Al}^{3+}\right)$, copper $\left(\mathrm{Cu}^{2+}\right)$, and selenate $\left(\mathrm{SeO}_{4}^{2-}\right)$ in wheat roots: A descriptive and mathematical assessment. Physiol. Plant. 139:68-79. doi:10.1111/j.1399-3054.2010.01347.x

Knicker, H. 2004. Stabilization of N-compounds in soil and organic-matterrich sediments-what is the difference? Mar. Chem. 92:167-195. doi:10.1016/j.marchem.2004.06.025

Kögel-Knabner, I. 2002. The macromolecular organic composition of plant and microbial residues as inputs to soil organic matter. Soil Biology and Biochemistry 34:139-162. doi: 10.1016/s0038-0717(01)00158-4.

Kondo, K., R. Uchida, S. Tokutake, and T. Maitani. 2006. Polymeric grape-seed procyanidins, but not monomeric catechins and oligomeric procyanidins, impair degranulation and membrane ruffling in RBL-2H3 cells. Bioorganic \& Medicinal Chemistry 14:641-649. doi: 10.1016/j.bmc.2005.08.051.

Kraus, T.E.C., R.A. Dahlgren, and R.J. Zasoski. 2003a. Tannins in nutrient 
dynamics of forest ecosystems-A review. Plant Soil 256:41-66. doi:10.1023/A:1026206511084

Kraus, T.E.C., Z. Yu, C.M. Preston, R.A. Dahlgren, and R.J. Zasoski. 2003b. Linking chemical reactivity and protein precipitation to structural characteristics of foliar tannins. J. Chem. Ecol. 29:703-730. doi:10.1023/A:1022876804925

Kuiters, A.T. 1990. Role of phenolic substances from decomposing forest litter in plant-soil interactions. Acta Bot. Neerl. 39:329-348.

Leinweber, P., H.R. Schulten, and M. Körschens. 1995. Hot water extracted organic matter: Chemical composition and temporal variations in a long-term field experiment. Biol. Fertil. Soils 20:17-23. doi:10.1007/BF00307836

Littell, R.C., G.A. Milliken, W.W. Stroup, and R.D. Wolfinger. 1996. SAS system for mixed models. SAS Inst., Cary, NC.

Lu, Z., G. Nie, P.S. Belton, H. Tang, and B.Zhao. 2006. Structure-activity relationship analysis of antioxidant ability and neuroprotective effect of gallic acid derivatives. Neurochem. Int. 48:263-274. doi:10.1016/j.neuint.2005.10.010

Luthy, R.G., G.R. Aiken, M.L. Brusseau, S.D. Cunningham, P.M. Gschwend, J.J. Pignatello et al. 1997. Sequestration of hydrophobic organic contaminants by geosorbents. Environ. Sci. Technol. 31:3341-3347. doi:10.1021/es970512m

Makoi, J., and P.A. Ndakidemi. 2007. Biological, ecological and agronomic significance of plant phenolic compounds in rhizosphere of the symbiotic legumes. Afr. J. Biotechnol. 6:1358-1368.

Matthews, S., I. Mila, A. Scalbert, and D.M.X. Donnelly. 1997. Extractable and non-extractable proanthocyanidins in barks. Phytochemistry 45:405-410. doi:10.1016/S0031-9422(96)00873-4

McAllister, T.A., K.A. Beauchemin, S.M. McGinn, X. Hao, and P.H. Robinson. 2011. Greenhouse gases in animal agriculture-Finding a balance between food production and emissions. Anim. Feed Sci. Technol. 166-167:1-6. doi:10.1016/j.anifeedsci.2011.04.057

McSweeney, C.S., B. Palmer, D.M. McNeill, and D.O. Krause. 2001. Microbial interactions with tannins: Nutritional consequences for ruminants. Anim. Feed Sci. Technol. 91:83-93. doi:10.1016/S0377-8401(01)00232-2

Min, B.R., T.N. Barry, G.T. Attwood, and W.C. McNabb. 2003. The effect of condensed tannins on the nutrition and health of ruminants fed fresh temperate forages: A review. Anim. Feed Sci. Technol. 106:3-19. doi:10.1016/S0377-8401(03)00041-5

Mutabaruka, R., K. Hairiah, and G. Cadisch. 2007. Microbial degradation of hydrolysable and condensed tannin polyphenol-protein complexes in soils from different land-use histories. Soil Biology \& Biochemistry 39:14791492. doi: 10.1016/j.soilbio.2006.12.036.

Pohlman, A.A., and J.G. McColl. 1989. Organic oxidation and manganese and aluminum mobilization in forest soils. Soil Sci. Soc. Am. J. 53:686-690. doi:10.2136/sssaj1989.03615995005300030006x

Powell, J.M., M.J. Aguerre, and M.A. Wattiaux. 2011. Dietary crude protein and tannin impact dairy manure chemistry and ammonia emissions from incubated soils. J. Environ. Qual. 40:1767-1774. doi:10.2134/jeq2011.0085

Powell, J.M., and G.A. Broderick. 2011. Transdisciplinary soil science research: Impacts of dairy nutrition on manure chemistry and the environment. Soil Sci. Soc. Am. J. 75:2071-2078. doi:10.2136/sssaj2011.0226

Pronk, G.J., K. Heister, and I. Kögel-Knabner. 2011. Iron oxides as major available interface component in loamy arable topsoils. Soil Sci. Soc. Am. J. 75:2158-2168. doi:10.2136/sssaj2010.0455

Quideau, S., D. Deffieux, C. Douat-Casassus, and L. Pouységu. 2011. Plant polyphenols: Chemical properties, biological activities, and synthesis. Angew. Chem. Int. Ed. 50:586-621 4. doi:10.1002/anie.201000044

Rillig, M.C., B.A. Caldwell, H.A.B. Wösten, and P. Sollins. 2007. Role of proteins in soil carbon and nitrogen storage: Controls on persistence. Biogeochemistry 85:25-44. doi:10.1007/s10533-007-9102-6

Robinson, D.A., N. Hockley, D.M. Cooper, B.A. Emmett, A.M. Keith, I. Lebron et al. 2013. Natural capital and ecosystem services, developing an appropriate soils framework as a basis for valuation. Soil Biology and Biochemistry 57:1023-1033. doi:10.1016/j.soilbio.2012.09.008.

Robinson, D.A., I. Lebron, and H. Vereecken. 2009. On the definition of the natural capital of soils: A framework for description, evaluation, and monitoring. Soil Sci. Soc. Am. J. 73:1904-1911. doi:10.2136/sssaj2008.0332

Rovira, P., and V.R. Vallejo. 2002. Labile and recalcitrant pools of carbon and nitrogen in organic matter decomposing at different depths in soil: An acid hydrolysis approach. Geoderma 107:109-141. doi: 10.1016/S00167061(01)00143-4.

Salminen, J.-P., and M. Karonen. 2011. Chemical ecology of tannins and other phenolics: We need a change in approach. Funct. Ecol. 25:325-338. doi:10.1111/j.1365-2435.2010.01826.x

SAS. 1999. SAS OnlineDoc', Version 8. SAS Inst., Cary, NC.

Schmidt, M., J. Halvorson, J. Gonzalez, and A. Hagerman. 2012. Kinetics and binding capacity of six soils for structurally defined hydrolyzable and condensed tannins and related phenols. J. Soils Sediments 12:366-375. doi:10.1007/s11368-011-0463-z

Schofield, J.A., A.E. Hagerman, and A. Harold. 1998. Loss of tannins and other phenolics from willow leaf litter. J. Chem. Ecol. 24:1409-1421. doi:10.1023/A:1021287018787

Smolander, A., S. Kanerva, B. Adamczyk, and V. Kitunen. 2012. Nitrogen transformations in boreal forest soils-does composition of plant secondary compounds give any explanations? Plant Soil 350:1-26. doi:10.1007/ s11104-011-0895-7

Soil Survey Staff. 1999. Soil taxonomy: A basic system of soil classification for making and interpreting soil surveys. U.S. Gov. Print. Office, Washington, DC.

Talbot, J., and A. Finzi. 2008. Differential effects of sugar maple, red oak, and hemlock tannins on carbon and nitrogen cycling in temperate forest soils. Oecologia 155:583-592. doi:10.1007/s00442-007-0940-7

Tilman, D., C. Balzer, J. Hill, and B.L. Befort. 2011. Global food demand and the sustainable intensification of agriculture. Proc. Natl. Acad. Sci. USA 108:20260-20264. doi:10.1073/pnas.1116437108

von Lützow, M., I. Kögel-Knabner, K. Ekschmitt, E. Matzner, G. Guggenberger, B. Marschner et al. 2006. Stabilization of organic matter in temperate soils: Mechanisms and their relevance under different soil conditions- a review. Eur. J. Soil Sci. 57:426-445. doi:10.1111/j.1365-2389.2006.00809.x

Xing, B. 1997. The effect of the quality of soil organic matter on sorption of naphthalene. Chemosphere 35: 633-642. doi: 10.1016/s00456535(97)00125-2. 